\title{
Increasing Vase Life of Tinted Spikes of Polianthes tuberosa Linn. cv. Prajwal by Adding Floral Preservatives
}

\author{
Bijay Kumar Baidya ${ }^{1 *}$ and Suhrita Chakrabarty ${ }^{2}$
}

${ }^{1}$ Department of Fruit Science and Horticulture Technology, College of Agriculture, OUAT, Bhubaneswar, Odisha, Pin- 751003, India

${ }^{2}$ Department of Post Harvest Technology, Faculty of Horticulture, Professor, AICRP on Floriculture, Bidhan Chandra Krishi Viswavidyalaya, Mohanpur, Nadia, West Bengal, Pin-741252, India

*Corresponding author

\section{A B S T R A C T}

\section{Keywords}

Tinting, Sucrose,

Citric acid,

Aluminium

sulphate, HQS

(Hydroxyquinoline

Sulfate), Orange

red, Apple green,

Lemon yellow vase

life, Acceptability

and Tuberose

Article Info

Accepted:

22 July 2020

Available Online:

10 August 2020

\begin{abstract}
The present study was conducted during 2017-18 to prolong the post-harvest life of tinted tuberose by using food dyes in combination with floral preservatives. The experiment was conducted in a completely randomized block design (factorial) with three replications and $24(2 \times 3 \times 4)$ treatments viz., Factor A: Duration of dipping (H1 - 2 hours, H2 - 3 hours), Factor B: Food dyes (D1 - Orange Red, D2 - Apple Green, D3 - Lemon Yellow), Factor C: Floral preservatives (T1 - no preservatives, T2 - Sucrose $(2 \%)+$ Citric acid 300ppm, T3 - Sucrose $(2 \%)+$ Aluminium Sulphate 200ppm, T4 - Sucrose (2\%) + HQS 200ppm). The results showed that dipping the spikes in Apple green 3\% + sucrose 2\% + HQS 200 ppm for 2 hours was the best treatment in terms of maintenance of fresh weight, opened florets, vase life and acceptability. It also revealed that sucrose $2 \%+$ aluminum sulphate treatment was found better after sucrose $2 \%+$ HQS 200ppm. However, sucrose $2 \%+$ aluminum sulphate showed a maximum diameter of florets as compared to sucrose $2 \%+\mathrm{HQS} 200 \mathrm{ppm}$. Among food dye, apple green $3 \%$ showed the best result as compared to the other two.
\end{abstract}

\section{Introduction}

Tuberose (Polianthes tuberosa L.) a member of family Amaryllidaceae, has originated from Mexico. Due to its pleasant fragrance, higher returns, and wide adaptability to varied climate and soil, tuberose is an important commercial cut as well as loose flower crop of India. It is valued much by the aesthetic world for the serene beauty and fragrance. Due to the absence of carotenoids and anthocyanins (Huang et al., 2002), all existing commercial varieties of tuberose lack colours in the petals and this is a major disadvantage 
sometimes. Growers of tuberose often face problems of marketing during the peak flowering season, where coloured spikes might have fetched better prices (Anonymous, 2019). Colour is one of the prime considerations for purchasing cut flowers (Jeom Hee Park et al., 2013). Also, flower colour is very sensitive to human emotions and affects a lot of psychological phenomena. Produce when subjected to a change for higher profit, is termed as value addition. Value added tuberose spikes can provide a great variety of colours for aesthetic beautification (Safeena et al., 2016). Tinting is one of the important value addition techniques which could be adopted in flower crops where colour pigments are either absent or not prominent. It enhances the aesthetic beauty of fresh and dry flowers (Sowmeya $e t$ al., 2017). Artificial colouring of spikes is fetching a more price in the market as compared to white ones. The technique of value addition like colouring of white flowers can add value up to 5 to 10 times (Mekala et al., 2012). However, when tuberose flowers are tinted there is a reduction of vase life compared to spikes without tinting (Kumari and Deb, 2018). Treatment of spikes without dye or only water exhibited higher vase life than that of dyed spikes. It is more desirable to have tuberose spikes with green, red, or yellow florets instead of white ones in vase or bouquets with better vase life and keeping quality. The tinted flowers will be very attractive and of good enchantment which holds excellence within the flower arrangements. But at the same time, the vase life of tinted flowers is less as compared to flowers which are not tinted. Hence, tinted flowers will be used to display for a short duration (Ranchana et al., 2017). The use of floral preservatives to promote the quality and to extend vase life has been known many years. Chemical preservatives are known to be antibacterial agents, water uptake enhancers along with other properties, are used for extending vase life of cut flowers (Kumari et al., 2018). There are many chemicals (floral preservatives) like sucrose, 8- HQS (Hydroxy Quinoline Sulphate), aluminum sulphate, citric acid, etc. which could be standardized as a combining agent of the existing food dyes.

Therefore, the present investigation was undertaken to study the effect of food dyes combined with floral preservatives on quality and vase life of tuberose spikes.

\section{Materials and Methods}

The present investigation was carried out at the laboratory of AICRP on Floriculture, Directorate of Research Complex, Kalyani, Bidhan Chandra Krishi Viswavidyalaya, Mohanpur, Nadia, and West Bengal. The experimental details and techniques employed in the study are described as follows:

\section{Experimental procedure}

The cut spikes of tuberose harvested at the commercial stage and the spikes were treated with food dyes (orange-red 3\%, apple green $3 \%$, lemon yellow 3\%) in combination with citric acid $300 \mathrm{ppm}$, aluminium sulphate 200ppm and HQS 200ppm for 2 and 3 hours of dipping. The basal pairs of leaves were removed and slant cut at the base of the spike was given before placing them in the solution. The spikes are allowed to absorb the solution under ambient conditions. After 2 and 3 hours of dipping duration, the spikes are taken out and kept in a test tube containing distilled water.

The experiment was conducted in a Completely Randomized Block Design (Factorial) with three replications and 24 (2X3X4) treatments viz., Factor A: Duration of dipping ( $\mathrm{H} 1-2$ hours, $\mathrm{H} 2-3$ hours), Factor B: Food dyes (D1 - Orange Red, D2 - 
Apple Green, D3 - Lemon Yellow), Factor C: Floral preservatives $(\mathrm{T} 1-$ no preservatives, $\mathrm{T} 2$ - Sucrose $(2 \%)+$ Citric acid 300ppm, T3 - Sucrose $(2 \%)+$ Aluminium Sulphate 200ppm, T4 - Sucrose (2\%) + HQS 200ppm).

\section{Laboratory condition}

The temperature measured in Celsius scale and relative humidity, measured by hygrometer inside the laboratory during the experiments. The average light intensity inside the laboratory was 250 lux. The average temperature during the experiments was $31.74^{\circ} \mathrm{C}$ and relative humidity was $68.6 \%$.

\section{Observations recorded}

Observations such as the quantity of dye uptake $(\mathrm{ml} / \mathrm{spike})$, water uptake $(\mathrm{ml} / \mathrm{spike})$, floret diameter $(\mathrm{cm})$, vase life (day), colour intensity (using colour chart- mini RHS, Fig. 1 and Table 4), acceptability on the visual basis (1-9 hedonic scale suggested by Ranganna, 1997) were recorded.

The fresh weight of flowers was measured using a weighing balance. Change in fresh weight (\%) and percent of open flowers was calculated using the below formula:

\section{Change in fresh weight (\%)}

$=\frac{\text { Spike weight on day of observation }- \text { Initial spike weight }}{\text { Initial spike weight }} \times 100$

Percent of open flowers

$=\frac{\text { No.of open flowers on the day of observation }}{\text { Total number of flowers }} \times 100$

\section{Statistical analysis}

The experiment included three replications for each treatment. The design adopted was a Factorial Completely Randomized Design (CRD) method used for calculating the variance of the experiment. When two or more factors are tested simultaneously to see if they independently interact with each other, the experiment is called factorial experiment (Mahalanobis, 1932).

\section{Results and Discussion}

A perusal of data (Table 1) revealed that all the holding solutions in different treatments were significantly affected the vase life of spikes. Vase life of spikes was recorded by calculating the number of days. The results of interaction effects showed that dipping the cut spikes for 2 hours in apple green and lemonyellow dyes combined with citric acid, HQS and Aluminium sulphate (H1D2T2, H1D3T4, and H1D3T3) resulted in maximum vase life (3.50 days). Whereas minimum vase life of 2 days was observed in the solution containing only dye without any preservatives. Thus, it was clearly visible that vase life of tinted tuberose flowers increased with the incorporation of sucrose in dye solution along with floral preservatives like citric acid, HQS, and Alluminium sulphate. This result corroborates with the finding of earlier workers (Murthy and Negi, 1981 and Reddy et al., 1997). They also opined that carbohydrates being the main source of nutrition for cut flowers, helped in maintaining all biochemical and physiological processes for prolonging vase life. Increased vase life due to aluminum sulphate combined with sucrose was reported by Reddy and Singh (1996) who found that $500 \mathrm{ppm}$ aluminum sulphate in combination with sucrose $4 \%$ significantly enhanced the vase life of tuberose spikes. According to Viradia et al., (2015) $\mathrm{Al}_{2} \mathrm{SO}_{4} 500 \mathrm{ppm}+$ sucrose $2 \%$ significantly enhanced the fresh weight, uptake of water, vase life, and also found minimum physiological loss of weight and loss: uptake ratio. Also, Varu and Barad (2007) documented in tuberose and roses that less microbial growth in vase solution containing aluminum sulphate (as a result of 
lower $\mathrm{pH}$ ) prevented vascular blockages and facilitated greater solution uptake.

A significant variation was observed among the treatments in terms of change (gain or loss) in fresh weight (\%). Positive values indicate weight gain (percent) whereas negative values indicate weight loss (percent) in the Table 1. Among the different floral preservative solutions, which differed significantly, T4(sucrose 2\% + HQS 200ppm) showed maximum weight gain percent $(6.88 \%)$ followed by T3- sucrose $2 \%+$ aluminum sulphate $200 \mathrm{ppm}(6.23 \%)$ on $1 \mathrm{st}$ day in vase. Also, a significant percentage of weight loss was observed with different floral preservative solutions on 3rd day. T3- sucrose $2 \%$ + aluminum sulphate 200ppm showed minimum weight loss percent $(-5.12 \%)$ followed by T2- sucrose $2 \%+$ citric acid $300 \mathrm{ppm}(-5.16 \%)$ and maximum weight loss percent $(-8.40 \%)$ was observed in T1- only dye no preservatives on 3rd day of the treatment. Whereas in interaction effects, apple green $3 \%+$ sucrose $2 \%+$ HQS 200 ppm(H1D2T3) with 2 hours dipping in solution showed maximum weight gain percent $(3.29 \%)$ followed by apple green 3\% + sucrose $2 \%+$ citric acid $300 \mathrm{ppm}$ (H1D2T2) and apple green 3\% + sucrose 2\% + HQS 200 ppm (H1D2T4) and rest showed weight loss. This result might be due to the cumulative effect of sucrose and HQS (Fig. 2-7).

A combination of sucrose and 8-HQS maintained high values of fresh weight throughout the vase life of the spikes. 8-HQS incorporated with sucrose maintained higher rates of fresh weight and also delayed weight loss of the spikes. A similar trend was noticed by Marousky (1969) due to the interaction of sucrose and 8-HQS. Maintenance of fresh weight, water uptake, and water loss may fluctuate cyclically. The balance of water uptake and water loss affects the fresh weight change as reported by Halvey and Mayak (1981). Significant variations in the solutions (dye or dye combined with preservatives) uptake by the tinted spikes were also observed with different treatments as shown in Table 1, Fig. 8 and 9. With an increase in dipping duration, dye uptake by the spikes also increased. By the end of 3 hours dipping, the mean uptake of dye was $4.40 \mathrm{ml} / 100 \mathrm{~g}$ of spike, whereas 2 hours exhibited a mean value of $3.39 \mathrm{ml} / 100 \mathrm{~g}$ of spike. Among different dyes, apple green $(3 \%)$ recorded the highest uptake of dye $(4.18 \mathrm{ml} / 100 \mathrm{~g}$ of spike $)$ followed by orange-red $3 \%(3.89 \mathrm{ml} / 100 \mathrm{~g}$ of spike) and lemon yellow 3\% (3.62 ml/100g of spike). Regarding floral preservative, sucrose $2 \%$ + HQS 200ppm (T4) recorded maximum uptake of dye $(4.08 \mathrm{ml} / 100 \mathrm{~g}$ of spike) followed by $\mathrm{T} 1$ (only dye without any preservative) resulting $3.87 \mathrm{ml}$ of dye uptake $/ 100 \mathrm{~g}$ of spike. Among different interaction effects, highest uptake of dye $(4.99 \mathrm{ml} / 100 \mathrm{~g}$ of spike) was found in the spikes treated with apple green $3 \%+$ sucrose $2 \%+$ HQS 200ppm solution (H2D2T4) followed by apple green $3 \%+$ sucrose $2 \%+$ citric acid 300ppm solution (4.98 ml/100g of spike) at 3 hours of dipping. The lowest uptake of $3.04 \mathrm{ml} / 100 \mathrm{~g}$ of spike was recorded in the spikes treated with orange-red $3 \%+$ sucrose $2 \%+$ citric acid 300ppm (H1D1T2) at 2 hours of dipping.

Significant variations in the water uptake by the tinted spikes were also observed with different treatments as shown in Table 2, Fig. 10 and 11 . The results showed that there is a reduction in water uptake when the spikes were tinted. Whereas, untreated spikes (control) were found with higher water uptake. These results were also supported by Ranchana et al., (2017) where they observed that the tinted inflorescence of China aster was noticed with reduced water uptake. Whereas, untreated inflorescence (control) was found with higher water uptake. Among the main effects, the maximum uptake of 
water $(21 \mathrm{ml} / 100 \mathrm{~g}$ of spike) was observed in 2 hours of dipping (H1) on $1^{\text {st }}$ day after treatment. Among different dyes, the maximum uptake of water $(27.23 \mathrm{ml} / 100 \mathrm{~g}$ of spike) was observed in apple green $3 \%$ (D2) whereas in lemon yellow 3\% minimum (D3) water uptake $(11.53 \mathrm{ml} / 100 \mathrm{~g}$ of spike) was observed. As far as floral preservatives solutions are concerned, the maximum uptake of water $(20.80 \mathrm{ml} / 100 \mathrm{~g}$ of spike) was observed in sucrose 2\% + HQS 200ppm (T4) whereas in sucrose $2 \%+$ citric acid 300ppm (T2) minimum water uptake $(18.20 \mathrm{ml} / 100 \mathrm{~g}$ of spike) was observed on $1^{\text {st }}$ day after treatment. On 3rd day after treatment, between the durations of dipping, the maximum uptake of water $(3.70 \mathrm{ml} / 100 \mathrm{~g}$ of spike) was observed in 2 hours of dipping (H1). Considering different dyes, the maximum uptake of water $(3.60 \mathrm{ml} / 100 \mathrm{~g}$ of spike) was observed in 3\% orange-red (D1) whereas in $3 \%$ lemon yellow minimum water uptake $(2.00 \mathrm{ml} / 100 \mathrm{~g}$ of spike) was observed. As far as floral preservatives solutions are concerned, the maximum uptake of water $(3.53 \mathrm{ml} / 100 \mathrm{~g}$ of spike) was observed in sucrose $2 \%+$ HQS 200ppm (T4) whereas in sucrose $2 \%+$ aluminum sulphate 200ppm (T3) minimum water uptake $(2.59 \mathrm{ml} / 100 \mathrm{~g}$ of spike) was observed. Regarding interactions, the highest water uptake of $7.02 \mathrm{ml} / 100 \mathrm{~g}$ of spike was found in the spikes treated with apple green $3 \%+$ sucrose $2 \%+$ HQS 200 ppm solution (H1D2T4) followed by $5.54 \mathrm{ml} / 100 \mathrm{~g}$ of spike in the spikes treated with orange-red $3 \%$ with no preservatives (H1D1T1) at 2 hours of dipping. The lowest uptake of $0.45 \mathrm{ml} / 100 \mathrm{~g}$ of spike was recorded in the spikes treated with lemon yellow $3 \%$ with no preservatives (H2D3T1) at 3 hours of dipping. The chemical like 8-HQS and sucrose might have inhibited vascular blockage and increased absorption of the solution, ultimately increased the uptake of water in the spikes. This might be due to the combining effect of $8 \mathrm{HQS}+$ sucrose which inhibits vascular blockage and acidifies the solution with reduced microbial load, promotes more uptake of water in comparison to water loss ultimately resulting in higher water balance with minimum loss-uptake ratio. Similar results were found by Babu et. al (2001). Song et al., (1992) found the highest uptake of water in spikes treated with 8-HQS and sucrose. Vascular blockage of stems normally caused water deficit due to reduced water uptake. An effective germicide inhibits vascular occlusion and can extend the water uptake rate (Van Meteren et al., 2001).

Further, the significant influence of different chemical solutions as single and in combined form was observed in terms of percent of open flowers (Table 3). On 3rd day after treatment, between the durations of dipping, the maximum percent of open flowers (49.20\%) was observed in 2 hours of dipping (H1). Considering different dyes, the maximum percent of open flowers $(49.88 \%)$ was observed in apple green 3\% (D2). The results were also in agreement with those of Kumari et al., where they reported that the maximum number of florets was opened in Apple green treated spikes.

As far as floral preservatives solutions are concerned, the maximum percent of open flowers $(41.42 \%)$ was observed sucrose $2 \%+$ HQS 200ppm (T4). Among the interactions, the highest percent of open flowers of $91.67 \%$ was found in the spikes treated with apple green $3 \%+$ sucrose $2 \%+\mathrm{HQS} 200 \mathrm{ppm}$ solution (H1D2T4). Similar findings were also reported by Varu and Barad (2007), he stated that 8-HQS $400 \mathrm{ppm}+$ sucrose $4 \%$ showed maximum floret longevity and floret circumference as well as the maximum percentage of opened and lowest percentage of neck bent florets of tuberose spikes.

The results (Table 2) of this investigation also indicated that between dipping duration, 
maximum floret diameter $(3.27 \mathrm{~cm})$ was recorded in 2 hours of dipping (H1). Considering different dyes, maximum basal floret diameter $(3.73 \mathrm{~cm})$ was observed in apple green $3 \%$ (D2) whereas in orange-red $3 \%$ minimum (D1) basal floret diameter $(2.15 \mathrm{~cm})$ was observed. As far as floral preservatives solutions are concerned, maximum floret diameter $(3.23 \mathrm{~cm})$ was observed sucrose $2 \%+$ aluminum sulphate 200ppm (T3) along with sucrose $2 \%+$ citric acid 300ppm (T2) whereas in T1- no preservatives minimum floret diameter $(3.02 \mathrm{~cm})$ was observed. Regarding interaction effect, maximum floret diameter of $4.17 \mathrm{~cm}$ was found in the spikes treated with apple green $3 \%+$ sucrose $2 \%+$ HQS 200ppm solution (H1D3T4) at 2 hours of dipping followed by $4 \mathrm{~cm}$ in the spikes treated with lemon yellow 3\% with no preservatives (H1D3T1) at 2 hours of dipping. The minimum floret of $1.83 \mathrm{~cm}$ was recorded in both the spikes treated with orange red3\% with no preservatives (H1D1T1) at 2 hours of dipping and orange-red $3 \%$ with no preservatives (H2D1T1) at 3 hours of dipping. Similar findings were reported by Ichimura $e t$ al., (1999) that the cut roses (Rosa hybrida) cv. Sonia when treated with 8 - HQS (200 ppm) and Sucrose (3\%) showed an increase in flower diameter, fresh weight, and vase life at the. These results were also supported by Song et al., (1992), they observed that the sucrose + 8-HQS extended vase life 1.5 to 1.6 times than the control and improved flower quality significantly by increasing the number of flowers, flower diameter, fresh weight and solution uptake in gladiolus.

It is evident from the data presented in Table 2 (Fig. 12) that on the $2^{\text {nd }}$ day after treatment, between the durations of dipping, maximum acceptability score of 8.48 was observed in 2 hours of dipping (H1). Considering different dyes, maximum acceptability score (8.40) was observed in apple green 3\% (D2) whereas in orange-red $3 \%$ minimum acceptability score
(7.96) was observed. As far as floral preservatives solutions are concerned, maximum acceptability score (8.37) was observed in sucrose $2 \%+$ aluminum sulphate 200ppm (T3) followed by acceptability score of 8.36 in treatment with sucrose $2 \%+$ HQS 200ppm (T4) whereas in no preservatives (T1) minimum acceptability score (7.98) was observed. Regarding interactions effect, the highest acceptability score of 9 was found in the spikes treated with apple green $3 \%+$ sucrose $2 \%+$ aluminum sulphate 200ppm solution (H1D2T3) followed by 8.70 in the spikes treated with sucrose $2 \%+\mathrm{HQS}$ 200ppm (H1D2T4) at 2 hours of dipping. The minimum acceptability of 7.50 was recorded in both the spikes treated with lemon yellow 3\% (H2D3T1) and orange-red 3\% (H2D1T1) with no preservatives at 3 hours of dipping. Similar findings were stated by Reddy and Singh (1996) that the aluminum sulfate in combination with sucrose significantly enhanced the vase life and quality of tuberose spikes by increasing the water uptake and maintaining a better water balance and a higher fresh weight for longer periods. The optimum concentration for the combined treatment was $0.50 \mathrm{mM}$ aluminum sulfate and $4 \%$ sucrose.

On $3^{\text {rd }}$ day after treatment, both factors i.e. dipping duration and different dyes were found to have an acceptability score below 5 . But as far as floral preservatives solutions are concerned, only $2 \%$ sucrose + aluminum sulphate 200ppm (T3) showed maximum acceptability (5.03). Regarding interactions, highest acceptability score of 5.23 was found in the spikes treated with apple green $3 \%+$ sucrose 2\% + HQS 200ppm (H2D2T4) at 3 hours of dipping followed by acceptability score of 5.20 in treatments i.e. apple green 3\% + aluminum sulphate 200ppm (H1D2T3) and lemon yellow $3 \%+$ sucrose $2 \%+$ aluminum sulphate 200ppm (H1D3T3) when the dipping duration was 2 hours. 
Table.1 Effect of dipping duration, different dyes, and floral preservatives along with their interaction on vase life, quantity of dye uptake, and change in fresh weight of Tuberose

(Polianthes tuberosa L.) cv. Prajwal

\begin{tabular}{|c|c|c|c|c|c|c|c|}
\hline \multirow[t]{2}{*}{ Treatments } & \multirow{2}{*}{$\begin{array}{l}\text { Vase life } \\
\text { (days) }\end{array}$} & \multirow{2}{*}{$\begin{array}{l}\text { Quantity of dye } \\
\text { uptake }(\mathrm{ml} / 100 \mathrm{~g} \\
\text { of spike) }\end{array}$} & \multicolumn{5}{|c|}{ Change in fresh weight $(\%)$} \\
\hline & & & $\begin{array}{c}\text { Due to } \\
\text { dipping }\end{array}$ & $1^{\text {st }}$ day & $2^{\text {nd }}$ day & $3^{\text {rd }}$ day & $4^{\text {th }}$ day \\
\hline \multicolumn{8}{|c|}{ Factor A: Dipping duration } \\
\hline H1(2 hour) & 2.97 & 3.39 & 0.80 & 7.08 & 3.42 & -3.11 & -21.59 \\
\hline H2(3 hour) & 2.61 & 4.40 & 1.16 & 5.31 & -1.47 & -9.01 & -27.49 \\
\hline S.Em & 0.02 & 0.08 & 0.09 & 0.22 & 0.29 & 0.40 & 1.00 \\
\hline CD at $5 \%$ & 0.05 & 0.23 & 0.24 & 0.61 & 0.83 & 1.14 & 2.84 \\
\hline \multicolumn{8}{|l|}{ Factor B: Dyes } \\
\hline D1 (OR) & 2.73 & 3.89 & 0.99 & 4.64 & -1.08 & -7.68 & -28.07 \\
\hline D2 (AG) & 2.90 & 4.18 & 1.09 & 8.81 & 4.80 & -1.20 & -22.51 \\
\hline D3 (LY) & 2.75 & 3.62 & 0.87 & 5.14 & -0.81 & -9.31 & -23.05 \\
\hline S.Em & 0.02 & 0.10 & 0.10 & 0.26 & 0.36 & 0.49 & 1.22 \\
\hline CD at $5 \%$ & 0.07 & 0.28 & NS & 0.75 & 1.01 & 1.40 & 3.48 \\
\hline \multicolumn{8}{|c|}{ Factor C: Floral preservatives } \\
\hline T1 & 2.50 & 3.87 & 0.84 & 5.53 & 0.03 & -8.40 & -28.29 \\
\hline T2 & 2.67 & 3.79 & 0.98 & 6.15 & 1.75 & -5.16 & -24.12 \\
\hline T3 & 2.83 & 3.84 & 1.07 & 6.23 & 0.99 & -5.12 & -19.46 \\
\hline T4 & 3.17 & 4.08 & 1.04 & 6.88 & 1.12 & -5.58 & -26.30 \\
\hline S.Em & 0.02 & 0.11 & 0.12 & 0.30 & 0.41 & 0.57 & 1.41 \\
\hline CD at $5 \%$ & 0.06 & NS & NS & 0.87 & 1.17 & 1.61 & 4.02 \\
\hline \multicolumn{8}{|c|}{ Factor A X B X C } \\
\hline H1D1T1 & 2.00 & 3.36 & 0.45 & 5.56 & 3.00 & -4.10 & -28.16 \\
\hline H1D1T2 & 3.00 & 3.04 & 0.67 & 5.34 & 1.35 & -3.40 & -22.56 \\
\hline H1D1T3 & 3.00 & 3.11 & 1.88 & 6.46 & 2.62 & -4.70 & -27.11 \\
\hline H1D1T4 & 3.00 & 3.34 & 0.93 & 5.85 & 0.78 & -5.08 & -26.08 \\
\hline H1D2T1 & 2.50 & 3.65 & 0.58 & 10.02 & 5.14 & -0.98 & -21.69 \\
\hline H1D2T2 & 3.50 & 3.25 & 0.80 & 7.78 & 6.84 & 2.48 & -11.73 \\
\hline H1D2T3 & 3.33 & 3.46 & 0.95 & 10.36 & 7.16 & 3.29 & -15.98 \\
\hline H1D2T4 & 3.33 & 3.81 & 0.69 & 9.94 & 7.14 & 1.21 & -23.64 \\
\hline H1D3T1 & 2.00 & 3.35 & 1.37 & 5.86 & 0.98 & -6.91 & -22.36 \\
\hline H1D3T2 & 3.00 & 3.38 & 0.50 & 5.91 & 2.25 & -7.69 & -26.02 \\
\hline H1D3T3 & 3.50 & 3.49 & 0.46 & 5.93 & 2.11 & -5.30 & -12.45 \\
\hline H1D3T4 & 3.50 & 3.44 & 0.32 & 5.96 & 1.65 & -6.19 & -21.30 \\
\hline H2D1T1 & 2.00 & 4.31 & 0.68 & 0.70 & -8.16 & -16.42 & -36.85 \\
\hline H2D1T2 & 2.50 & 4.14 & 1.03 & 4.53 & 1.72 & -7.30 & -32.43 \\
\hline H2D1T3 & 2.50 & 4.61 & 0.95 & 4.11 & -3.37 & -7.95 & -17.57 \\
\hline H2D1T4 & 2.50 & 5.18 & 1.35 & 4.58 & -6.55 & -12.45 & -33.81 \\
\hline H2D2T1 & 2.00 & 4.65 & 0.92 & 7.35 & 4.11 & -4.27 & -29.48 \\
\hline H2D2T2 & 2.50 & 4.98 & 1.68 & 8.28 & 1.89 & -4.40 & -27.26 \\
\hline H2D2T3 & 3.00 & 4.67 & 1.20 & 7.15 & 0.93 & -4.86 & -26.51 \\
\hline H2D2T4 & 3.33 & 4.99 & 1.87 & 9.56 & 5.22 & -2.07 & -23.78 \\
\hline H2D3T1 & 2.00 & 3.90 & 1.05 & 3.71 & -4.88 & -17.69 & -31.18 \\
\hline H2D3T2 & 3.00 & 3.93 & 1.19 & 5.04 & -3.56 & -10.64 & -24.71 \\
\hline H2D3T3 & 3.00 & 3.72 & 0.97 & 3.37 & -3.47 & -11.19 & -17.13 \\
\hline H2D3T4 & 3.00 & 3.76 & 1.09 & 5.38 & -1.53 & -8.88 & -29.22 \\
\hline S.Em & 0.06 & 0.27 & 0.29 & 0.75 & 1.01 & 1.39 & 3.46 \\
\hline CD at $5 \%$ & 0.17 & NS & $\mathrm{NS}$ & NS & 2.87 & 3.95 & 9.84 \\
\hline Control & 2.00 & NA & 2.38 & 4.26 & 0.93 & -1.80 & -15.57 \\
\hline
\end{tabular}

*Control - Without any dye and preservatives, NS - Non - significant, NA - Not applicable

* (-) indicates Weight loss

*OR- Orange-red 3\%, AG- Apple green 3\%, LY- Lemon yellow 3\%

*T1- no preservatives, T2- Sucrose $2 \%$ + Citric acid 300ppm. T3- Sucrose 2\% + Aluminium sulphate 200ppm, T4-

Sucrose $2 \%+$ HQS 200ppm 
Table.2 Effect of dipping duration, dyeing, floral preservatives, and their interaction on quantity of water uptake, floret diameter, and acceptability of

Tuberose spikes (Polianthes tuberosa L.) cv. Prajwal

\begin{tabular}{|c|c|c|c|c|c|c|c|}
\hline \multirow[t]{3}{*}{ Treatments } & \multicolumn{3}{|c|}{ Water uptake (ml per $100 \mathrm{~g}$ of spikes) } & \multirow{3}{*}{$\begin{array}{c}\text { Floret } \\
\text { diameter }(\mathbf{c m})\end{array}$} & \multirow{2}{*}{\multicolumn{3}{|c|}{ Acceptability (1-9 hedonic scale) }} \\
\hline & \multirow[t]{2}{*}{$1^{\text {st }}$ day } & \multirow[t]{2}{*}{$2^{\text {nd }}$ day } & \multirow[t]{2}{*}{$3^{\text {rd }}$ day } & & & & \\
\hline & & & & & $1^{\text {st }}$ day & $2^{\text {nd }}$ day & $3^{\text {rd }}$ day \\
\hline \multicolumn{8}{|c|}{ Factor A: Dipping duration } \\
\hline H1(2 hour) & 21.00 & 11.01 & 3.70 & 3.27 & 8.84 & 8.48 & 4.81 \\
\hline H2(3 hour) & 17.74 & 6.72 & 2.09 & 3.07 & 8.86 & 7.88 & 4.58 \\
\hline S.Em & 0.41 & 0.25 & 0.20 & 0.06 & 0.00 & 0.00 & 0.01 \\
\hline CD at $5 \%$ & 1.16 & 0.72 & 0.57 & 0.16 & 0.00 & 0.01 & 0.03 \\
\hline \multicolumn{8}{|l|}{ Factor B: Dyes } \\
\hline D1 (OR) & 19.35 & 9.20 & 3.60 & 2.15 & 8.82 & 7.96 & 4.52 \\
\hline D2 (AG) & 27.23 & 12.25 & 3.10 & 3.73 & 8.90 & 8.40 & 4.78 \\
\hline D3 (LY) & 11.53 & 5.13 & 2.00 & 3.63 & 8.83 & 8.18 & 4.78 \\
\hline S.Em & 0.50 & 0.31 & 0.25 & 0.07 & 0.00 & 0.00 & 0.01 \\
\hline CD at $5 \%$ & 1.41 & 0.89 & 0.70 & 0.20 & 0.00 & 0.01 & 0.04 \\
\hline \multicolumn{8}{|c|}{ Factor B: Floral preservatives } \\
\hline T1 & 19.32 & 8.67 & 2.79 & 3.02 & 8.58 & 7.98 & 4.21 \\
\hline $\mathbf{T 2}$ & 18.20 & 9.06 & 2.67 & 3.23 & 8.83 & 8.01 & 4.57 \\
\hline T3 & 19.15 & 7.91 & 2.59 & 3.23 & 9.00 & 8.37 & 5.03 \\
\hline T4 & 20.80 & 9.80 & 3.53 & 3.20 & 9.00 & 8.36 & 4.96 \\
\hline S.Em & 0.57 & 0.36 & 0.28 & 0.08 & 0.01 & 0.01 & 0.02 \\
\hline CD at $5 \%$ & 1.63 & 1.02 & NS & NS & 0.02 & 0.01 & 0.05 \\
\hline \multicolumn{8}{|c|}{ Factor A X B X C } \\
\hline H1D1T1 & 22.03 & 11.19 & 5.54 & 1.83 & 8.50 & 8.00 & 4.00 \\
\hline H1D1T2 & 19.45 & 10.23 & 4.33 & 2.67 & 8.80 & 8.23 & 4.60 \\
\hline H1D1T3 & 21.28 & 10.70 & 3.09 & 2.10 & 9.00 & 8.50 & 5.10 \\
\hline H1D1T4 & 22.45 & 10.06 & 3.64 & 2.00 & 9.00 & 8.50 & 5.00 \\
\hline H1D2T1 & 31.94 & 14.14 & 2.25 & 3.63 & 8.60 & 8.50 & 4.77 \\
\hline H1D2T2 & 27.33 & 12.12 & 2.80 & 3.43 & 8.80 & 8.20 & 4.67 \\
\hline H1D2T3 & 29.02 & 10.47 & 3.62 & 3.93 & 9.00 & 9.00 & 5.20 \\
\hline H1D2T4 & 32.96 & 18.21 & 7.02 & 3.93 & 9.00 & 8.70 & 5.00 \\
\hline H1D3T1 & 12.40 & 8.48 & 4.11 & 4.00 & 8.57 & 8.40 & 4.50 \\
\hline H1D3T2 & 10.21 & 9.45 & 3.01 & 3.67 & 8.87 & 8.20 & 4.67 \\
\hline H1D3T3 & 10.60 & 9.24 & 3.17 & 3.83 & 9.00 & 8.80 & 5.20 \\
\hline H1D3T4 & 12.28 & 7.77 & 1.84 & 4.17 & 9.00 & 8.69 & 5.00 \\
\hline H2D1T1 & 16.86 & 7.35 & 2.23 & 1.83 & 8.50 & 7.50 & 4.00 \\
\hline H2D1T2 & 16.74 & 8.09 & 2.96 & 2.67 & 8.77 & 7.53 & 4.27 \\
\hline H2D1T3 & 18.15 & 6.95 & 2.87 & 2.10 & 9.00 & 7.70 & 4.67 \\
\hline H2D1T4 & 17.80 & 8.99 & 4.09 & 2.00 & 9.00 & 7.70 & 4.50 \\
\hline H2D2T1 & 23.56 & 9.76 & 2.18 & 3.63 & 8.80 & 8.00 & 4.00 \\
\hline H2D2T2 & 23.05 & 13.05 & 1.88 & 3.43 & 9.00 & 8.20 & 4.40 \\
\hline H2D2T3 & 23.51 & 8.49 & 1.69 & 3.93 & 9.00 & 8.20 & 5.00 \\
\hline H2D2T4 & 26.49 & 11.78 & 3.34 & 3.93 & 9.00 & 8.40 & 5.23 \\
\hline H2D3T1 & 9.15 & 1.11 & 0.45 & 3.17 & 8.50 & 7.50 & 4.00 \\
\hline H2D3T2 & 12.42 & 1.43 & 1.04 & 3.50 & 8.73 & 7.70 & 4.83 \\
\hline H2D3T3 & 12.36 & 1.59 & 1.11 & 3.50 & 9.00 & 8.00 & 5.00 \\
\hline H2D3T4 & 12.82 & 1.99 & 1.24 & 3.17 & 9.00 & 8.17 & 5.00 \\
\hline S.Em & 1.41 & 0.88 & 0.70 & 0.20 & 0.02 & 0.01 & 0.04 \\
\hline CD at $5 \%$ & NS & 2.51 & 1.98 & NS & 0.05 & 0.03 & 0.11 \\
\hline Control & 28.90 & 13.29 & 9.27 & 3.43 & 9.00 & 8.00 & 4.50 \\
\hline
\end{tabular}

*Control - Without any dye and preservatives

*NS - Non - significant

*OR- Orange-red 3\%, AG- Apple green 3\%, LY- Lemon yellow 3\%

*T1- no preservatives, T2- Sucrose 2\% + Citric acid 300ppm. T3- Sucrose 2\% + Aluminium sulphate 200ppm, T4-

Sucrose 2\% + HQS 200ppm 
Table.3 Effect of dipping duration, dyeing, floral preservatives, and their interaction on flower opening (\%) of Tuberose spikes (Polianthes tuberosa L.) cv. Prajwal

\begin{tabular}{|c|c|c|c|}
\hline \multirow[t]{2}{*}{ Treatments } & \multicolumn{3}{|c|}{ Flower opening (\%) } \\
\hline & 1st day & 2nd day & 3rd day \\
\hline \multicolumn{4}{|c|}{ Factor A: Dipping duration } \\
\hline H1(2 hour) & 55.08 & 63.47 & 49.20 \\
\hline H2(3 hour) & 81.98 & 54.40 & 15.63 \\
\hline S.Em & 3.55 & 4.06 & 3.89 \\
\hline CD at $5 \%$ & 10.10 & NS & 11.06 \\
\hline \multicolumn{4}{|l|}{ Factor B: Dyes } \\
\hline D1 (OR) & 72.36 & 52.60 & 26.16 \\
\hline D2 (AG) & 66.71 & 74.47 & 49.88 \\
\hline D3 (LY) & 66.52 & 49.73 & 21.20 \\
\hline S.Em & 4.35 & 4.98 & 4.76 \\
\hline CD at $5 \%$ & NS & 14.15 & 13.55 \\
\hline \multicolumn{4}{|c|}{ Factor B: Floral preservatives } \\
\hline T1 & 77.70 & 59.88 & 24.29 \\
\hline T2 & 64.20 & 50.93 & 30.23 \\
\hline T3 & 64.33 & 57.51 & 33.71 \\
\hline T4 & 67.89 & 67.42 & 41.42 \\
\hline S.Em & 5.02 & 5.75 & 5.50 \\
\hline CD at $5 \%$ & NS & NS & NS \\
\hline \multicolumn{4}{|l|}{ Factor A X B X C } \\
\hline H1D1T1 & 66.67 & 55.55 & 5.56 \\
\hline H1D1T2 & 38.89 & 22.22 & 16.67 \\
\hline H1D1T3 & 87.78 & 95.24 & 62.06 \\
\hline H1D1T4 & 49.40 & 77.78 & 40.00 \\
\hline H1D2T1 & 64.35 & 100.00 & 75.93 \\
\hline H1D2T2 & 18.89 & 42.22 & 60.00 \\
\hline H1D2T3 & 52.81 & 86.67 & 68.89 \\
\hline H1D2T4 & 62.50 & 80.56 & 91.67 \\
\hline H1D3T1 & 56.04 & 28.15 & 22.60 \\
\hline H1D3T2 & 75.00 & 55.56 & 51.94 \\
\hline H1D3T3 & 37.65 & 51.52 & 49.62 \\
\hline H1D3T4 & 51.01 & 66.21 & 45.45 \\
\hline H2D1T1 & 100.00 & 33.33 & 13.33 \\
\hline H2D1T2 & 91.67 & 66.67 & 41.67 \\
\hline H2D1T3 & 58.33 & 28.33 & 13.33 \\
\hline H2D1T4 & 86.11 & 41.67 & 16.67 \\
\hline H2D2T1 & 100.00 & 88.89 & 28.33 \\
\hline H2D2T2 & 77.41 & 74.44 & 11.11 \\
\hline H2D2T3 & 66.67 & 27.78 & 8.33 \\
\hline H2D2T4 & 91.07 & 95.24 & 54.76 \\
\hline H2D3T1 & 79.17 & 53.33 & 0.00 \\
\hline H2D3T2 & 83.33 & 44.44 & 0.00 \\
\hline H2D3T3 & 82.73 & 55.56 & 0.00 \\
\hline H2D3T4 & 67.22 & 43.06 & 0.00 \\
\hline S.Em & 12.30 & 14.07 & 13.47 \\
\hline CD at $5 \%$ & 34.99 & 40.02 & NS \\
\hline Control & 57.41 & 31.11 & 0.00 \\
\hline
\end{tabular}

*Control - Without any dye and preservatives

*NS - Non - significant

*OR- Orange red 3\%, AG- Apple green 3\%, LY- Lemon yellow 3\%

*T1- no preservatives, T2- Sucrose 2\% + Citric acid 300ppm. T3- Sucrose 2\% + Aluminium sulphate 200ppm, T4Sucrose 2\% + HQS 200ppm 
Table.4 Colour intensity (RHS colour chart-mini) of tuberose spikes influenced by different treatments of food dyes, floral preservatives, and dipping duration

\begin{tabular}{|c|c|c|c|c|c|}
\hline \multirow{2}{*}{ Treatment } & \multicolumn{5}{|c|}{ Duration } \\
\hline & Before dip & After dip & 1 day & 2 day & 3 day \\
\hline H1D1T1 & RHS $155 \mathrm{C}$ & RHS 28B & RHS 28B & RHS $29 \mathrm{~A}$ & RHS $29 \mathrm{~A}$ \\
\hline H1D1T2 & RHS $155 \mathrm{C}$ & RHS 28B & RHS 28B & RHS $29 \mathrm{~A}$ & RHS $29 \mathrm{~A}$ \\
\hline H1D1T3 & RHS 155A & RHS 28A & RHS 28B & RHS $29 \mathrm{~A}$ & RHS $29 \mathrm{~A}$ \\
\hline H1D1T4 & RHS $155 \mathrm{C}$ & RHS 28A & RHS 288 & RHS 29A & RHS $29 \mathrm{~A}$ \\
\hline H1D2T1 & RHS $155 \mathrm{C}$ & RHS 141D & RHS 1410 & RHS 145A & RHS 145A \\
\hline H1D2T2 & RHS $155 \mathrm{C}$ & RHS 141D & RHS $145 \mathrm{~B}$ & RHS 1458 & RHS I $145 \mathrm{~A}$ \\
\hline H1D2T3 & RHS $155 \mathrm{C}$ & RHS 141D & RHS 1410 & RHS 1458 & RHS 145B \\
\hline H1D2T4 & RHS $155 \mathrm{C}$ & RHS 141D & RHS 145A & RHS 145A & RHS 145A \\
\hline H1D3T1 & RHS $155 \mathrm{C}$ & RHS 6 A & RHS 6 A & RHS $6 \mathrm{~A}$ & RHS 4A \\
\hline H1D3T2 & RHS $155 \mathrm{C}$ & RHS 4A & RHS 6 A & RHS $6 \mathrm{~A}$ & RHS $6 \mathrm{~A}$ \\
\hline H1D3T3 & RHS 156C & RHS 6 A & RHS $12 \mathrm{~A}$ & RHS $12 \mathrm{~A}$ & RHS $\triangle A$ \\
\hline H1D3T4 & RHS 1556 & RHS 4A & RHS $6 \mathrm{~A}$ & RHS 12A & RHS $6 \mathrm{~A}$ \\
\hline
\end{tabular}




\begin{tabular}{|c|c|c|c|c|c|}
\hline \multirow{2}{*}{ Treatment } & \multicolumn{5}{|c|}{ Duration } \\
\hline & Before dip & After dip & 1 day & 2 day & 3 day \\
\hline H2D1T1 & RHS $155 \mathrm{C}$ & RHS 28B & RHS 28A & RHS 24A & RHS $29 \mathrm{~A}$ \\
\hline H2D1T2 & RHS $155 \mathrm{C}$ & RHS 28B & RAIS 28A & RHS $29 \mathrm{~A}$ & RHS 29A \\
\hline H2D1T3 & RHS 155A & RHS 28A & RHS 28A & RHS $29 \mathrm{~A}$ & RHS $29 \mathrm{~A}$ \\
\hline H2D1T4 & RHS $155 \mathrm{C}$ & RHS 28A & RHS 28A & RHS 29A & RHS 29A \\
\hline H2D2T1 & RHS $156 \mathrm{C}$ & RHS 141D & RHS 145A & RHS 145B & RHS $145 A$ \\
\hline H2D2T2 & RHS $156 \mathrm{C}$ & RHS 141D & RHS $145 \mathrm{~A}$ & RHS 145B & RHS $145 \mathrm{~A}$ \\
\hline H2D2T3 & RHS $156 \mathrm{C}$ & PHS 1410 & RHS $145 B$ & RHS 1458 & RHS 1458 \\
\hline H2D2T4 & RHS $155 \mathrm{C}$ & RHS 141D & RHS $145 \wedge$ & RHS 145A & RHS 145B \\
\hline H2D3T1 & RHS $155 \mathrm{C}$ & RHS $\triangle A$ & RHS $6 \mathrm{~A}$ & RHS 4A & RHS 4A \\
\hline H2D3T2 & RHS $155 \mathrm{C}$ & RHS $6 \mathrm{~A}$ & RHS $6 A$ & RHS 4A & RHS 4A \\
\hline H2D3T3 & RHS 155A & RHS 4A & RHS 4A & RHS 4A & RHS 4A \\
\hline H2D3T4 & RHS $155 \mathrm{C}$ & RHS $4 \mathrm{~A}$ & RHS 6 A & RHS 6A & RHS $6 \mathrm{~A}$ \\
\hline Control & RHS $156 \mathrm{C}$ & RHS 155B & RHS 1558 & RHS 155B & RHS 1558 \\
\hline
\end{tabular}


Fig.1 RHS colour chart- mini

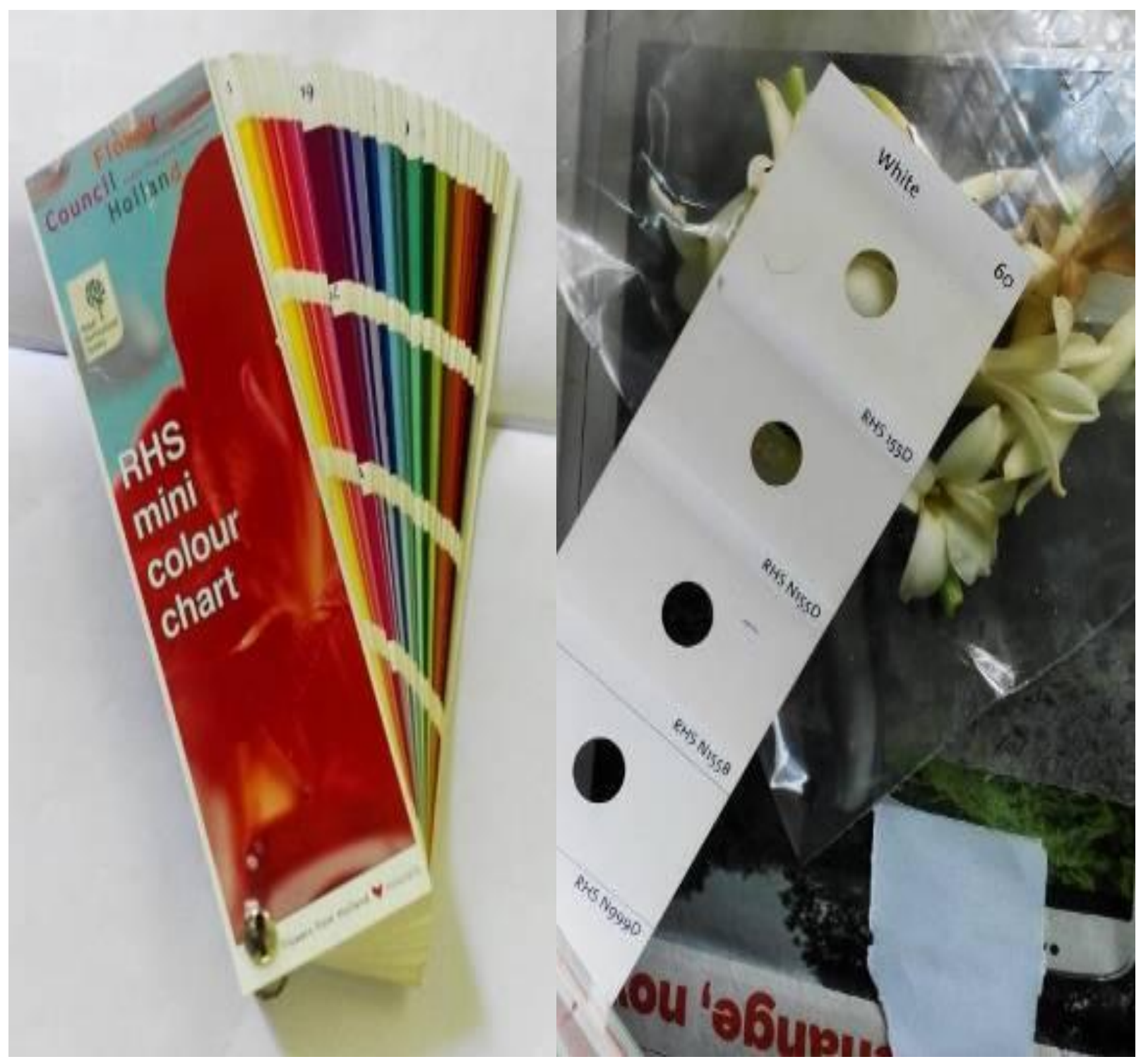


Fig.2 Effect of Orange-red 3\% (without any preservatives), Orange-red 3\% +Sucrose 2\%+HQS 200ppm, and Orange-red 3\% + Sucrose 2\% +Aluminium Sulphate 200ppm on tuberose spikes after 2 and 3 hours of dipping

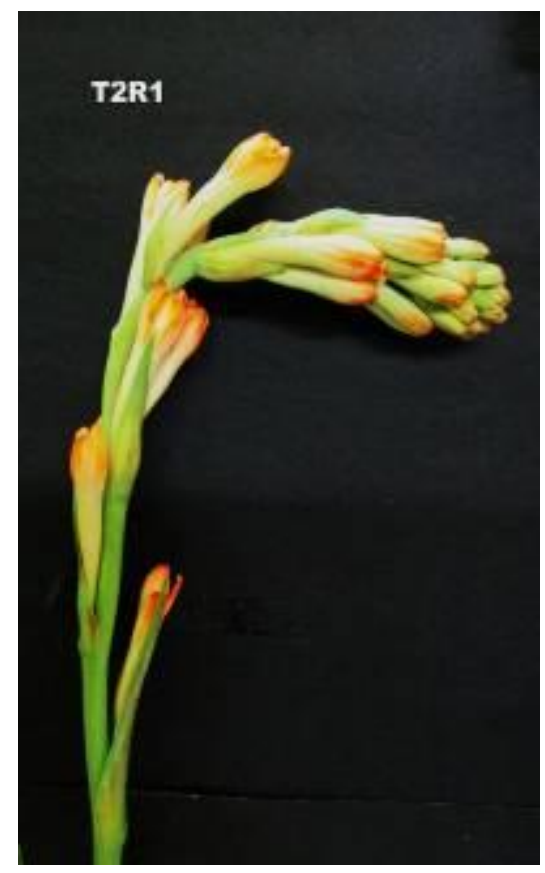

(Without any Preservatives)

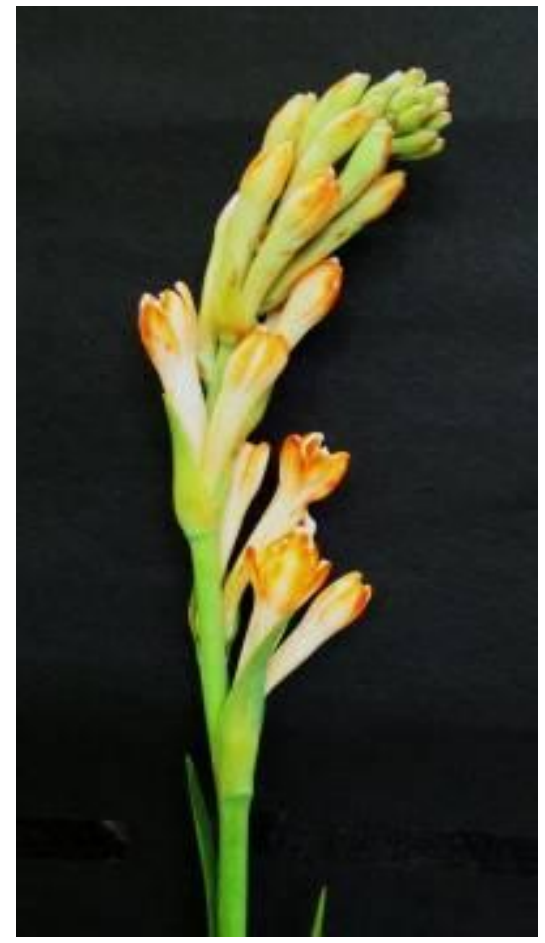

(Without any Preservatives)
(2 Hours of Dipping)

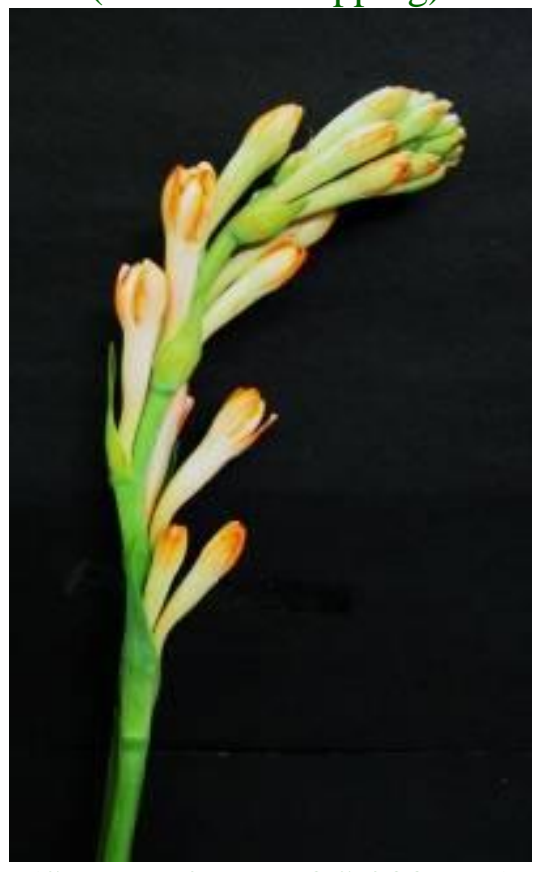

(Sucrose 2\% +HQS 200ppm)

\section{(3 hours of dipping)}

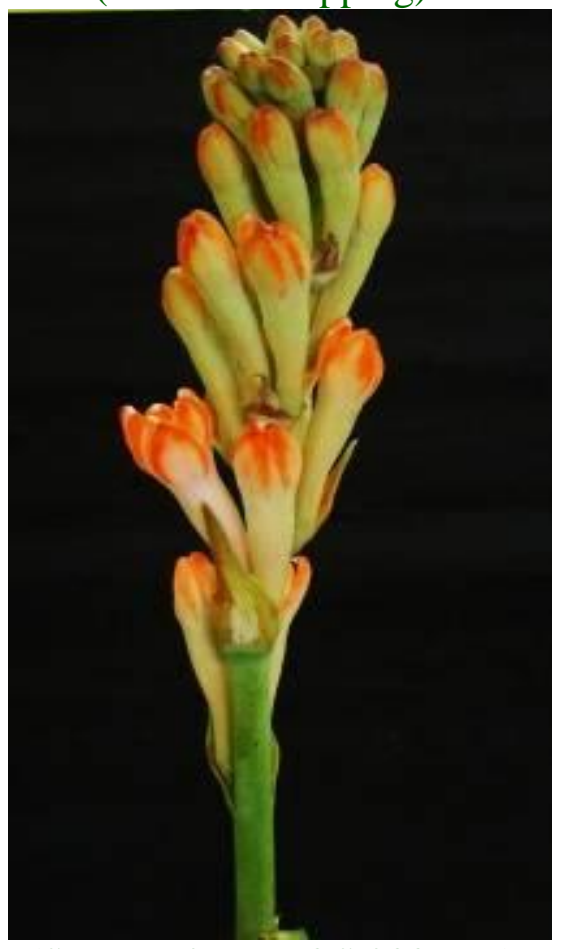

(Sucrose 2\% +HQS 200ppm)

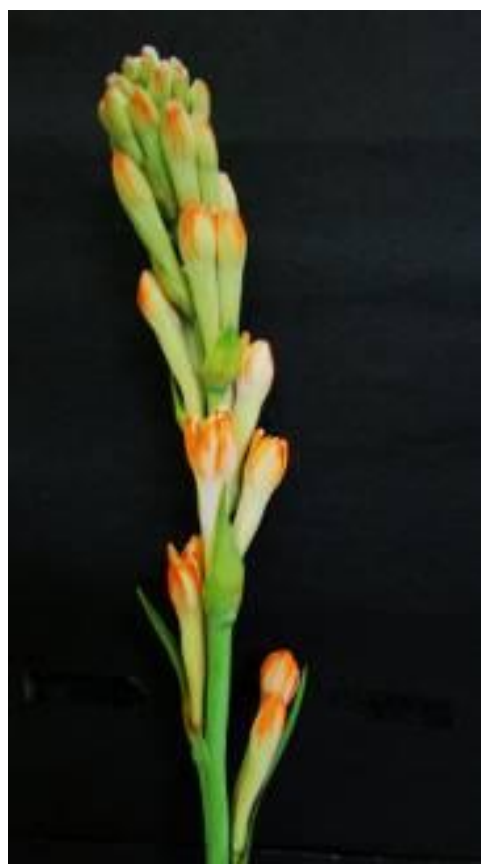

(Sucrose 2\% +Aluminium Sulphate 200ppm)

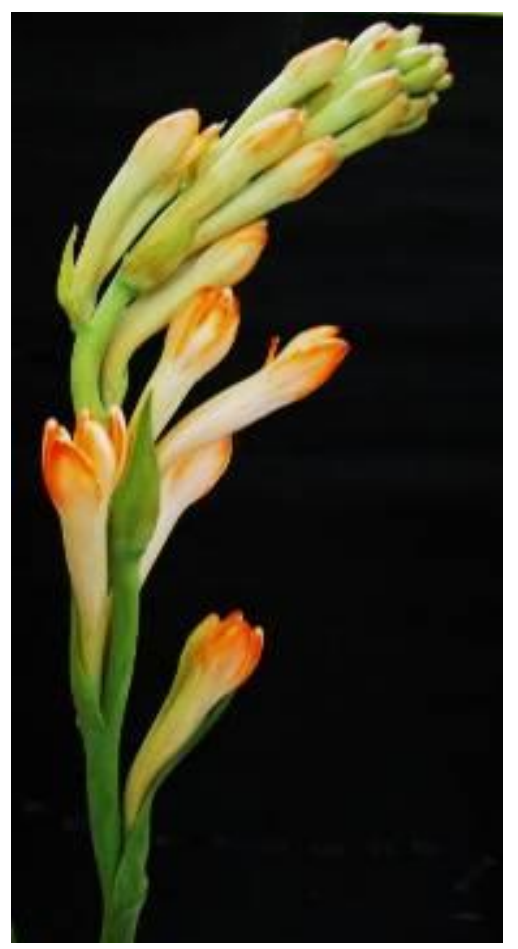

(Sucrose 2\% +Aluminium Sulphate 200ppm) 
Fig.3 Effect of Apple green 3\% (without any preservatives), Apple green 3\% + Sucrose 2\% +Aluminium Sulphate 200ppm, and Apple green 3\% +Sucrose 2\% +HQS 200ppm on tuberose spikes after 2 and 3 hours of dipping

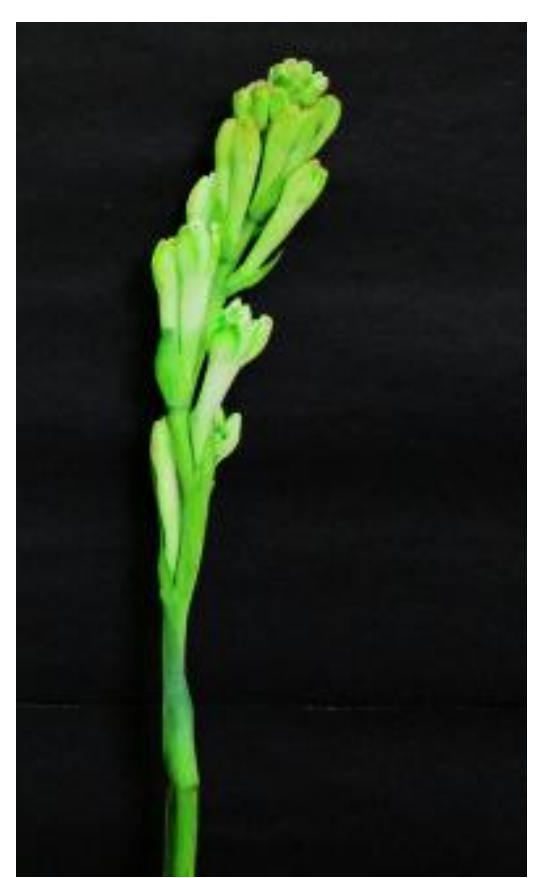

(Without any Preservatives)

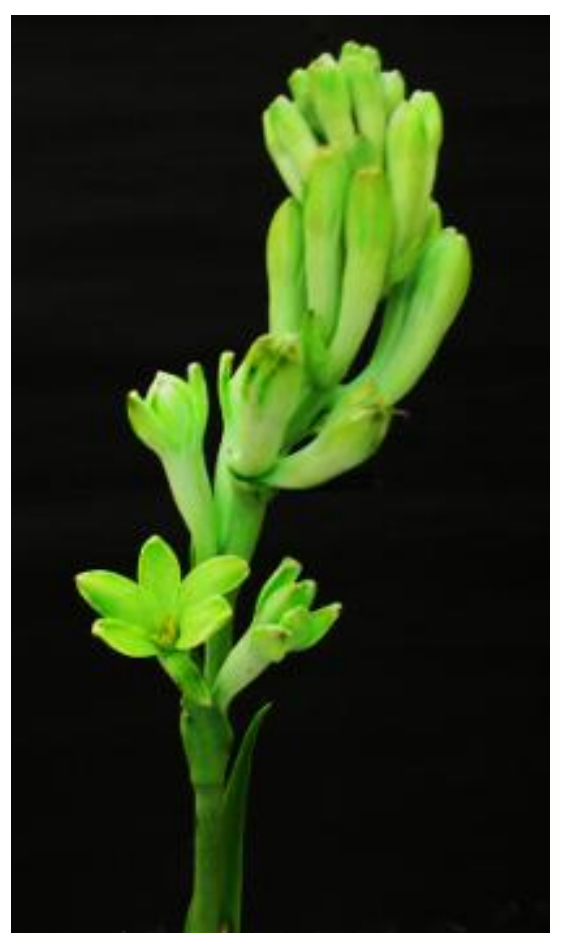

(Without any Preservatives)
(2 hours of dipping)

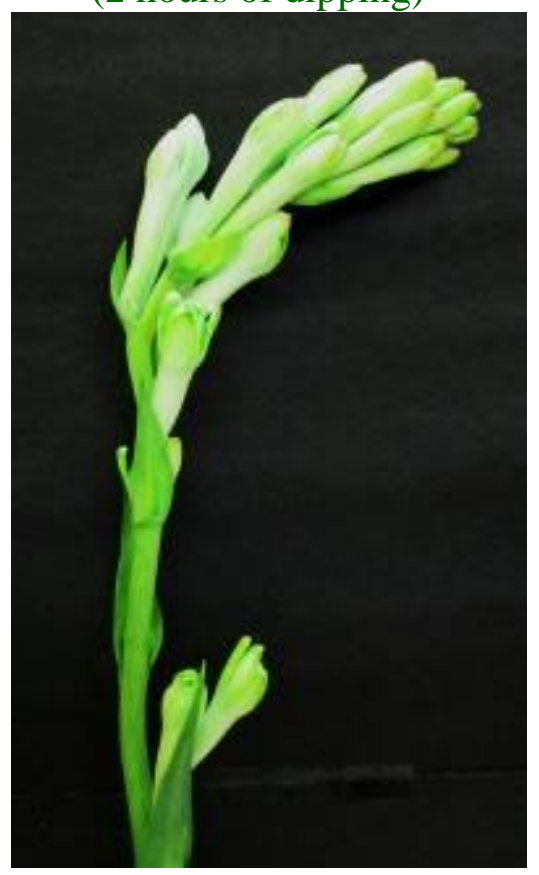

(Sucrose 2\% +HQS 200ppm

(3 hours of dipping)

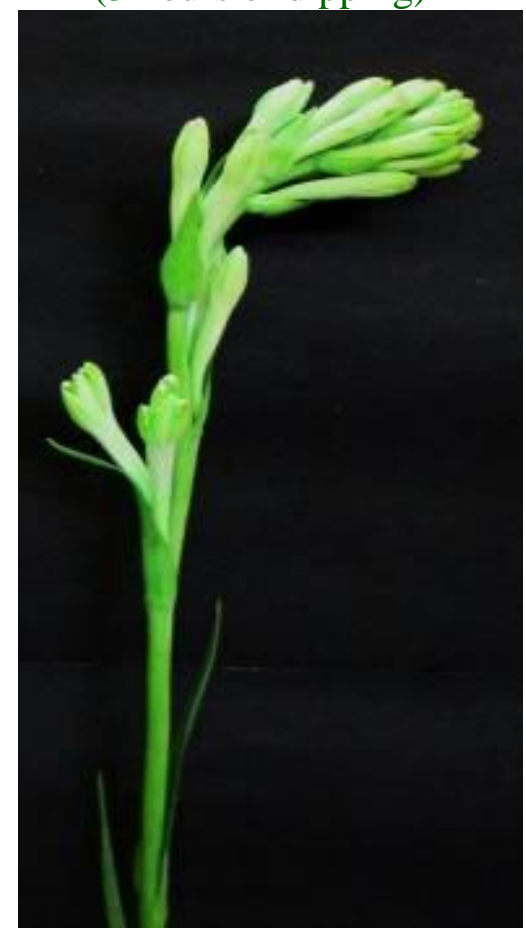

(Sucrose 2\% +HQS 200ppm)

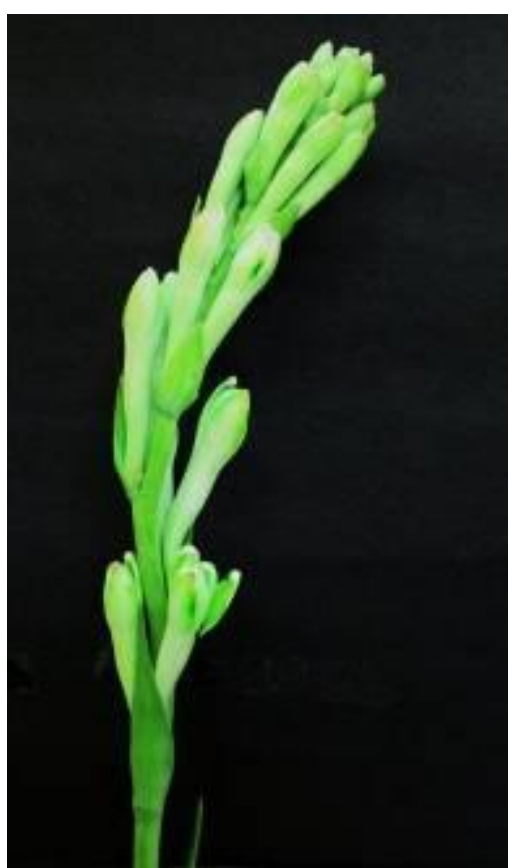

(Sucrose 2\% +Aluminium Sulphate 200ppm)

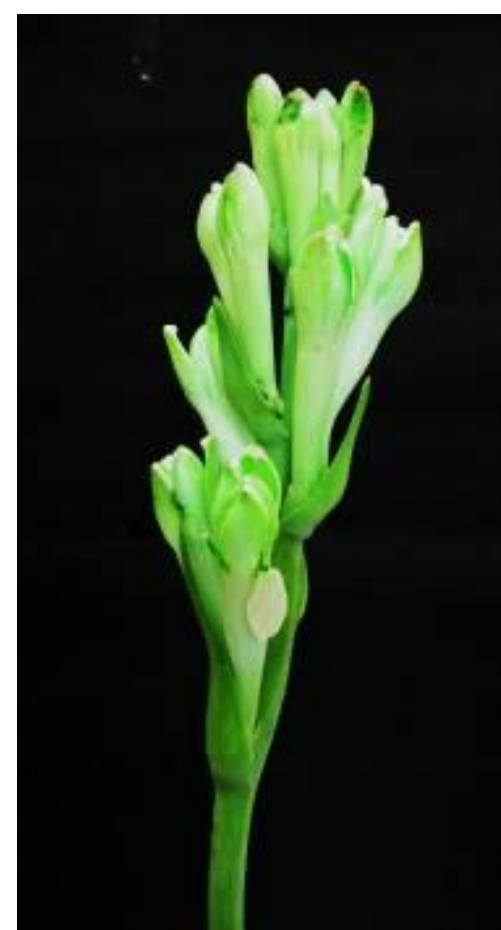

(Sucrose 2\% + Aluminium Sulphate 200ppm) 
Fig.4 Effect of Lemon yellow 3\% (without any preservatives), Lemon yellow 3\% + Sucrose 2\% +Aluminium Sulphate 200ppm, and Lemon yellow 3\% +Sucrose 2\% +HQS 200ppm on tuberose spikes after 2 and 3 hours of dipping

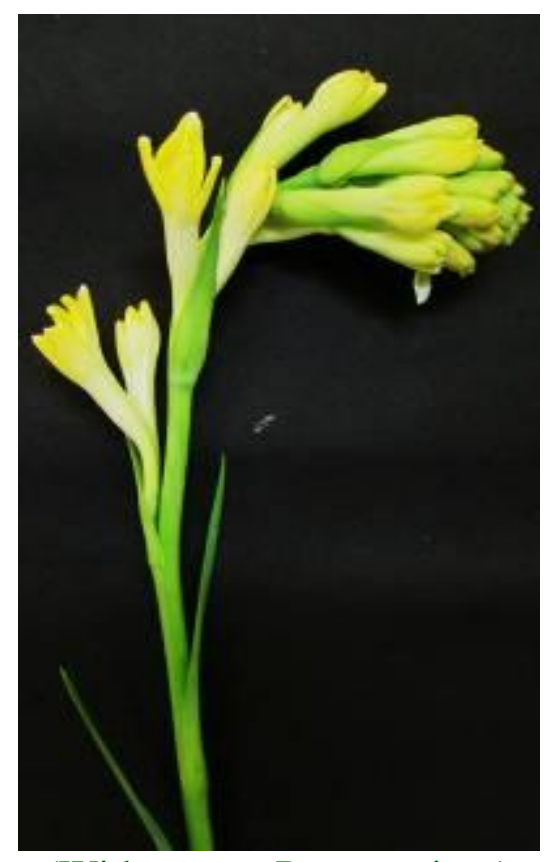

(Without any Preservatives)

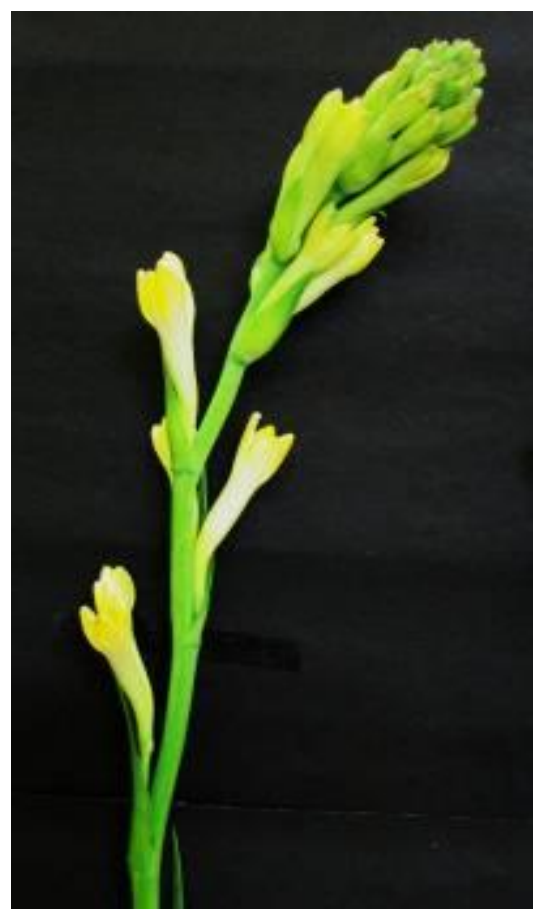

(Without any Preservatives)

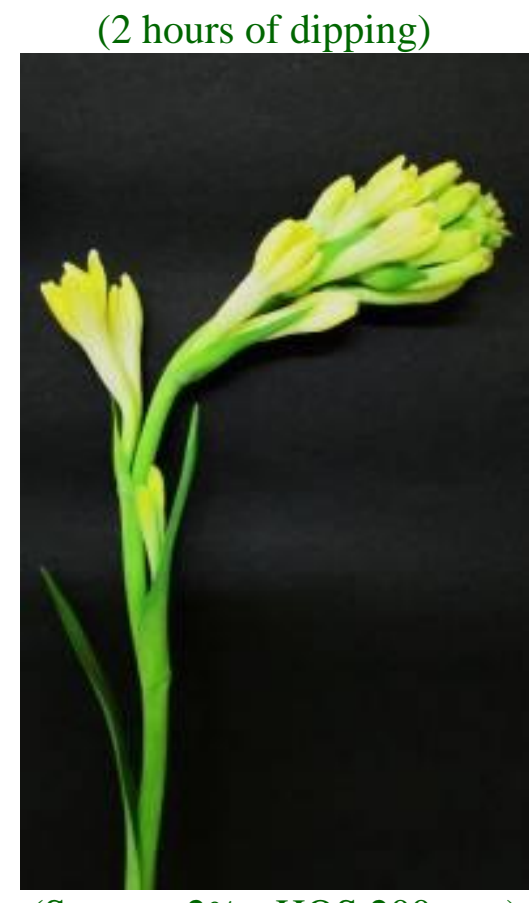

(Sucrose 2\% +HQS 200ppm)

(3 hours of dipping)

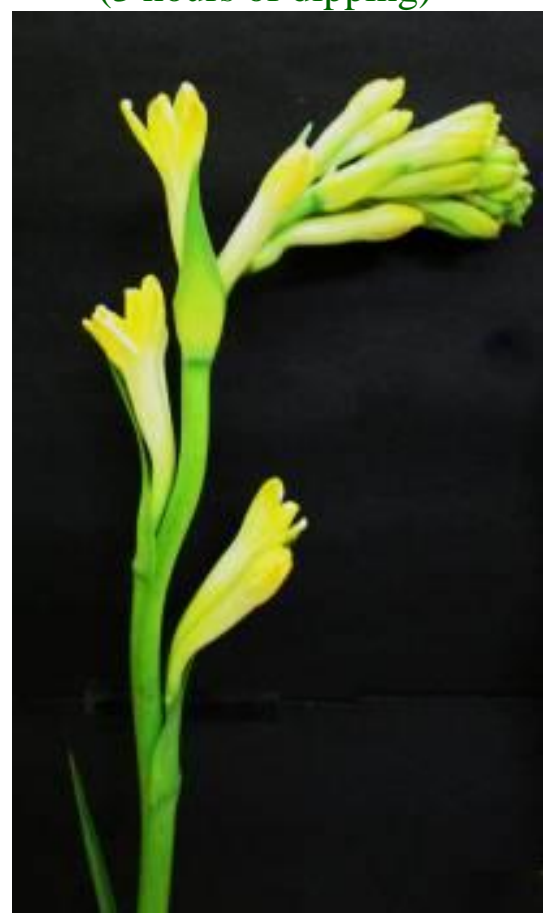

(Sucrose 2\% +HQS 200ppm

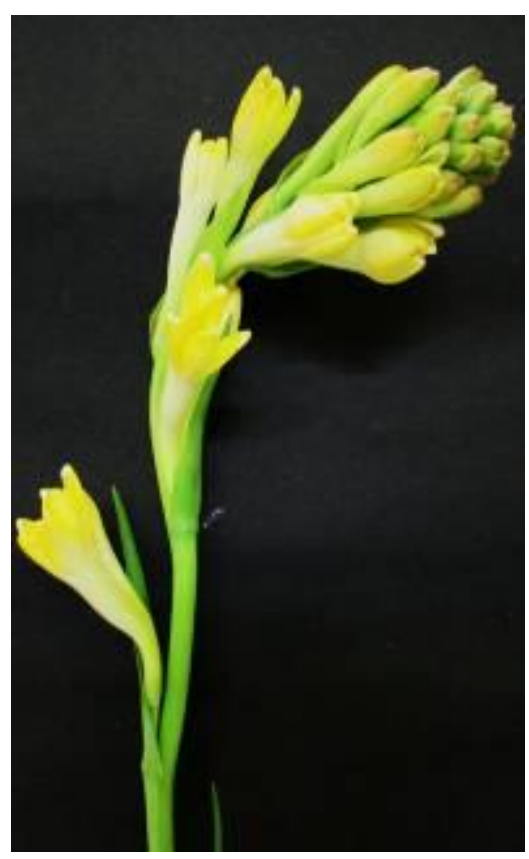

(Sucrose 2\% +Aluminium Sulphate 200ppm)

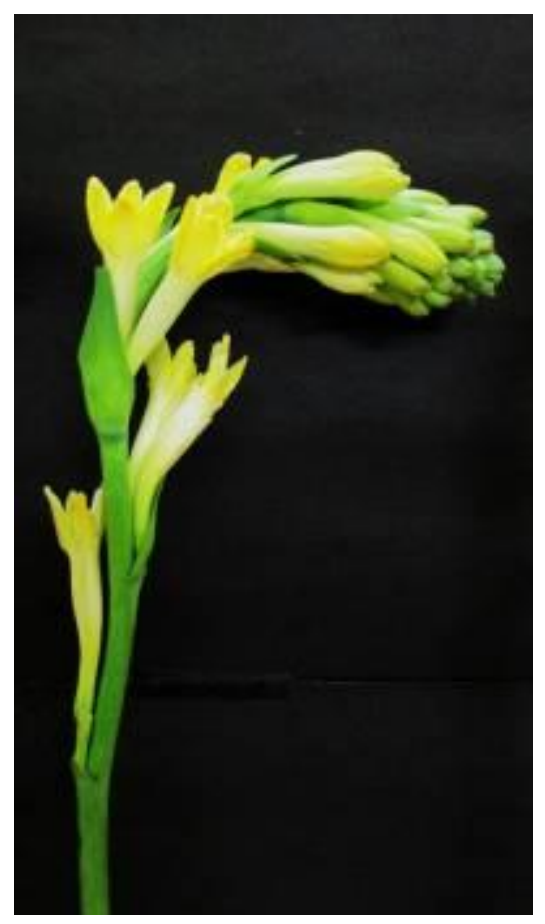

(Sucrose 2\% +Aluminium Sulphate 200ppm) 
Fig.5 Effect of Orange-red 3\% (without any preservatives), Orange-red 3\% +Sucrose 2\% +HQS 200ppm, and Orange-red 3\% + Sucrose 2\% +Aluminium Sulphate 200ppm on tuberose spikes

$$
\text { on } 2^{\text {nd }} \text { day }
$$

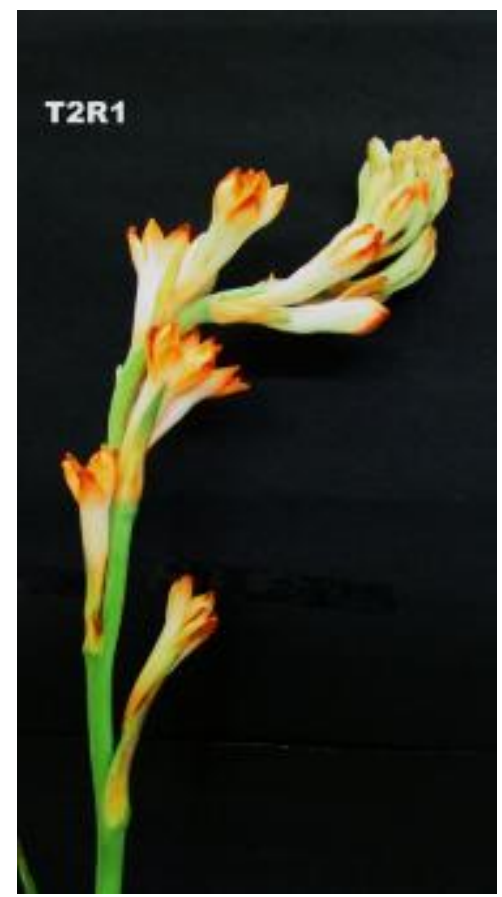

(Without any Preservatives)

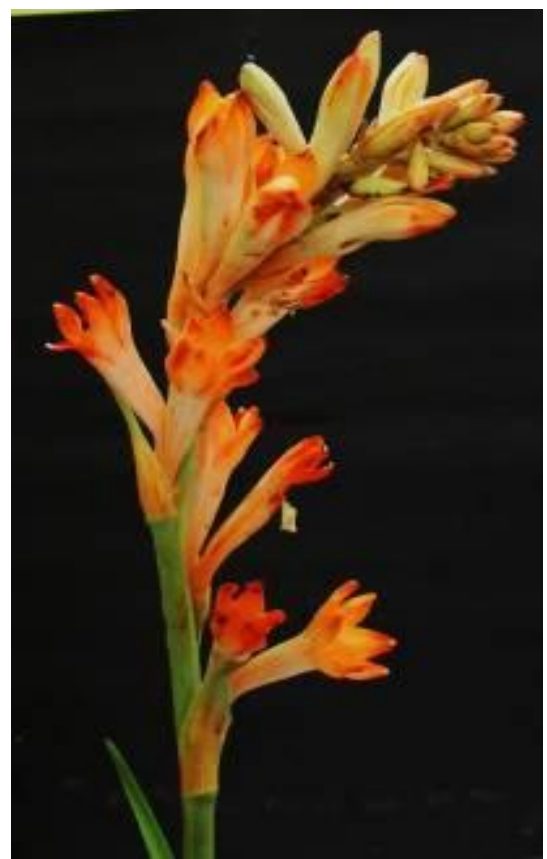

(Without any Preservatives)
(2 hours of dipping)

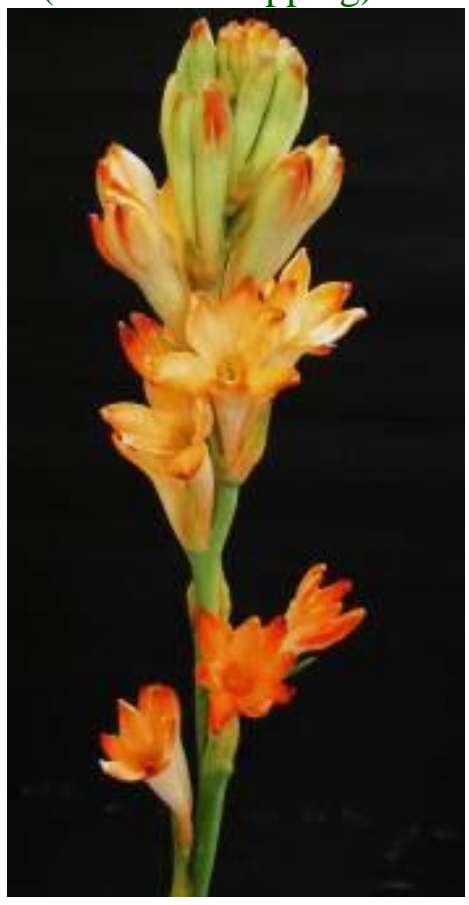

(Sucrose 2\%+HQS 200ppm)

(3 hours of dipping)

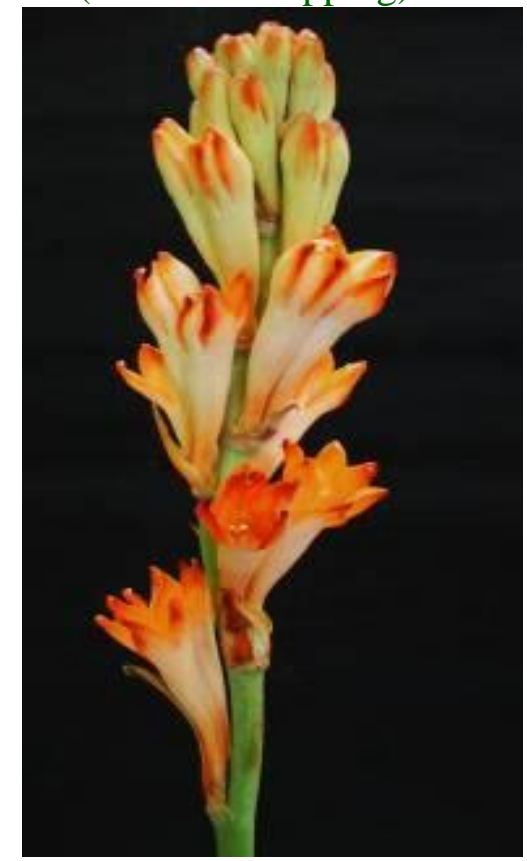

(Sucrose 2\% +HQS 200ppm

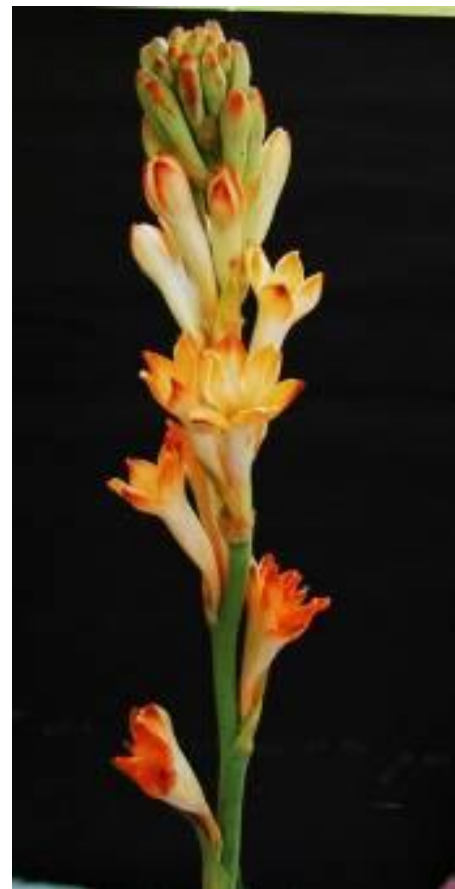

(Sucrose 2\% +Aluminium Sulphate 200ppm)

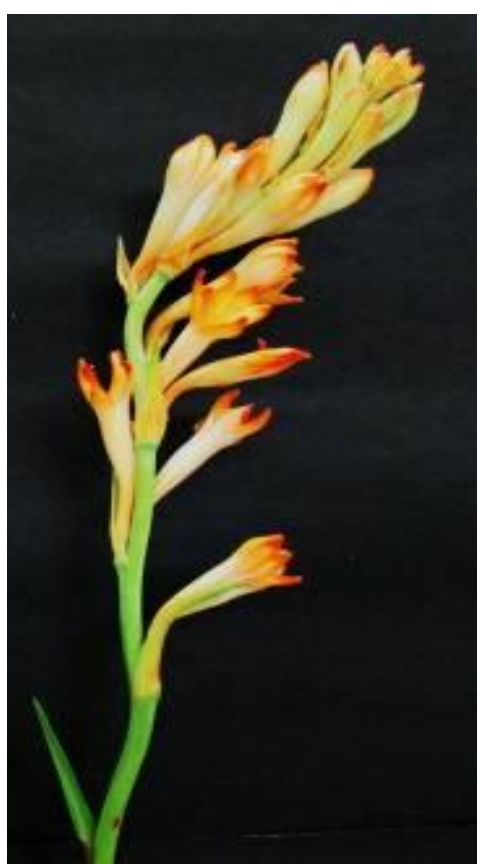

(Sucrose 2\% +Aluminium Sulphate 200ppm) 
Fig.6 Effect of Apple green 3\% (without any preservatives), Apple green 3\% + Sucrose 2\% +Aluminium Sulphate 200ppm and Apple green 3\% +Sucrose 2\%+HQS 200ppm on tuberose spikes on $2^{\text {nd }}$ day

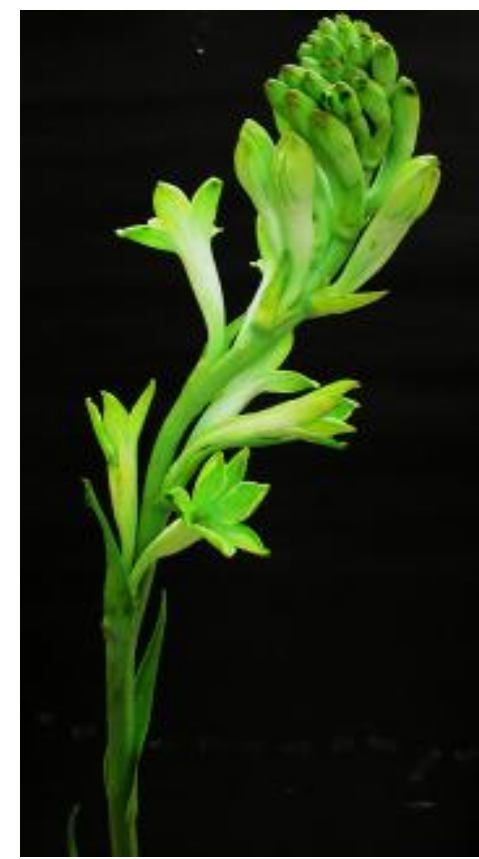

(Without any Preservatives)

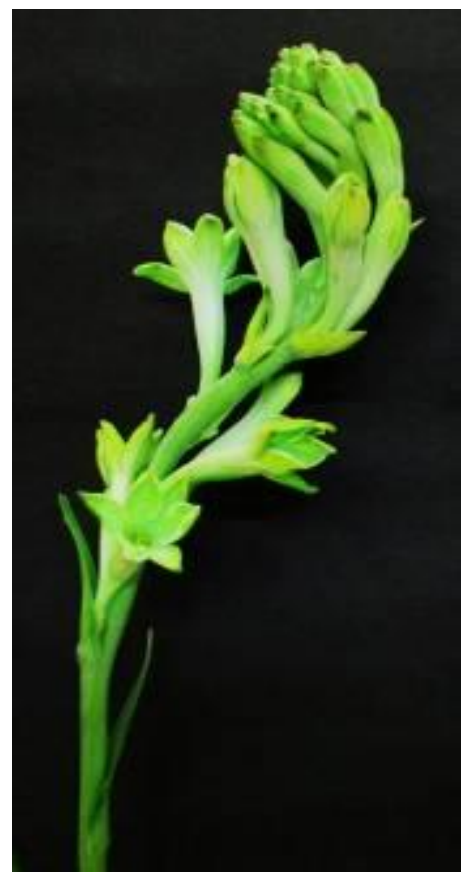

(Without any Preservatives)
(2 hours of dipping)
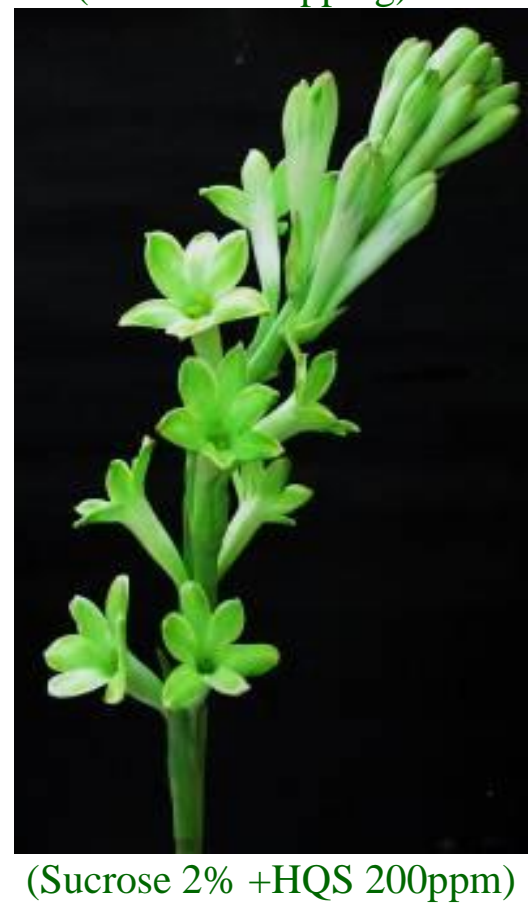

(3 hours of dipping)

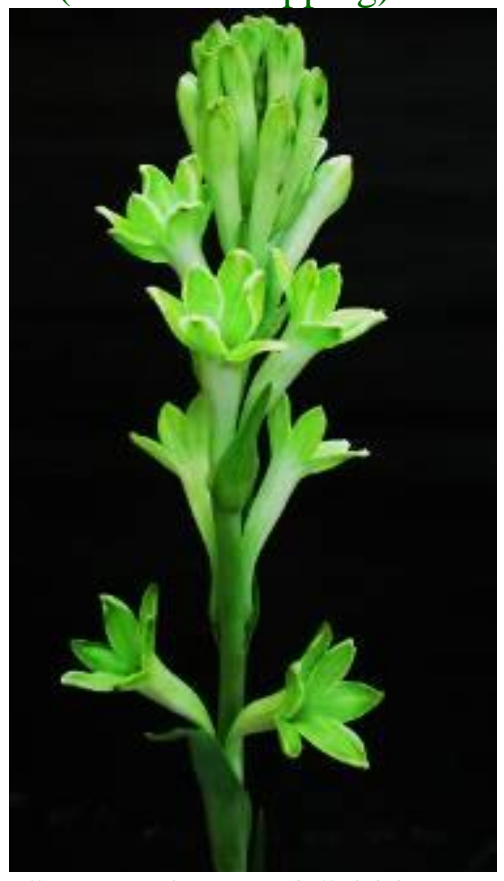

(Sucrose 2\% +HQS 200ppm)

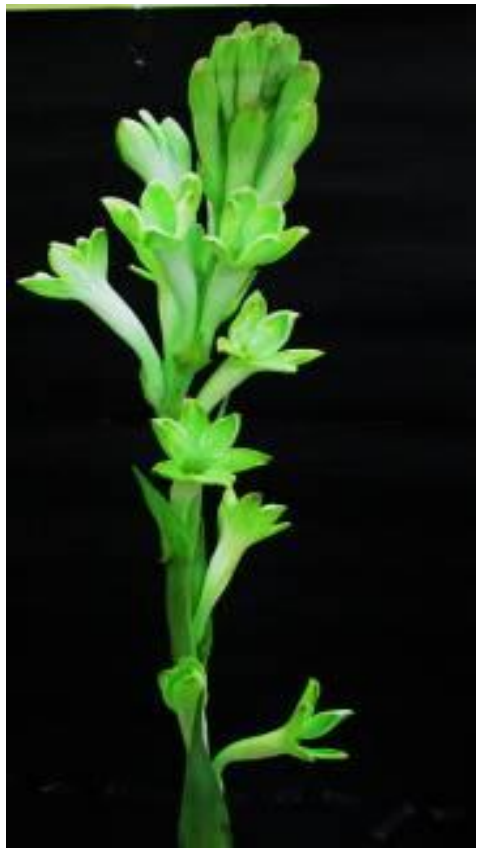

(Sucrose 2\% +Aluminium Sulphate 200ppm)

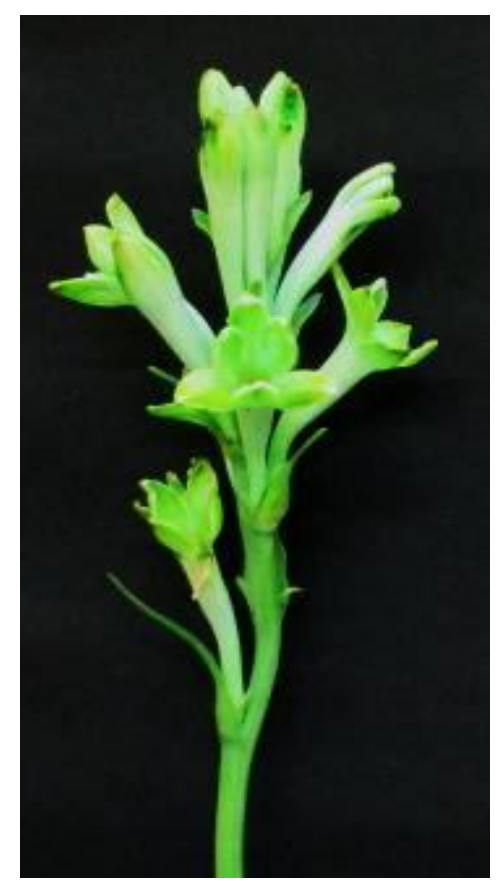

(Sucrose 2\% +Aluminium Sulphate 200ppm) 
Fig.7 Effect of Lemon yellow 3\% (without any preservatives), Lemon yellow 3\% + Sucrose 2\% +Aluminium Sulphate 200ppm, and Lemon yellow 3\% +Sucrose 2\% +HQS 200ppm on tuberose spikes on $2^{\text {nd }}$ day

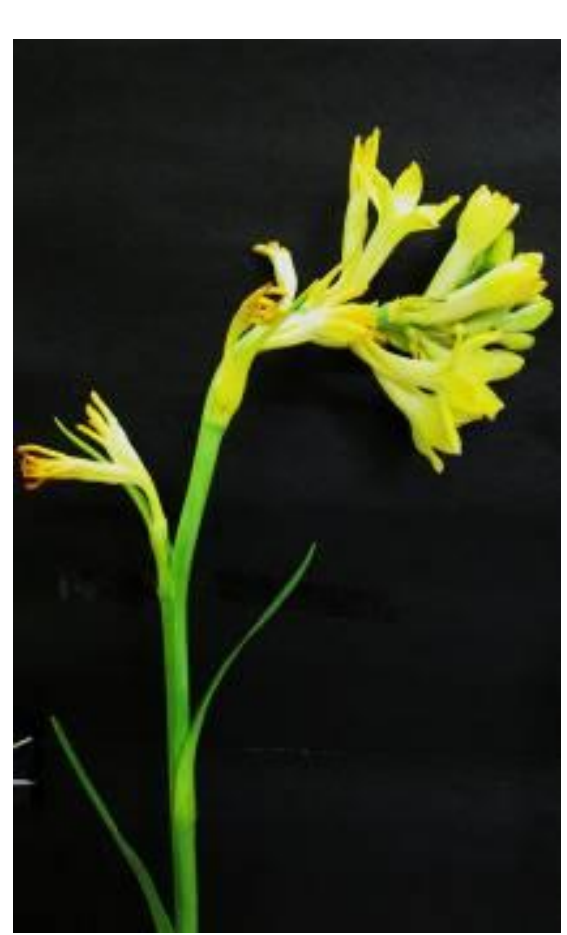

(Without any Preservatives)

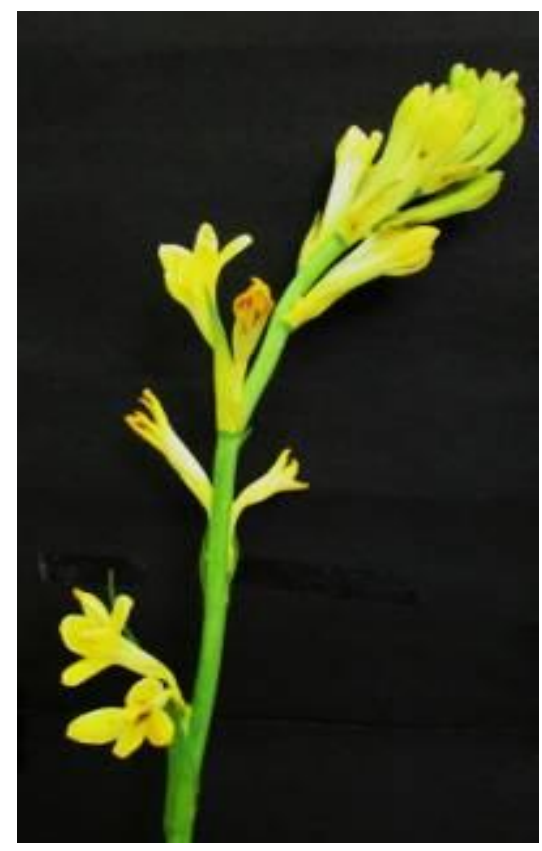

(Without any Preservatives)
(2 hours of dipping)

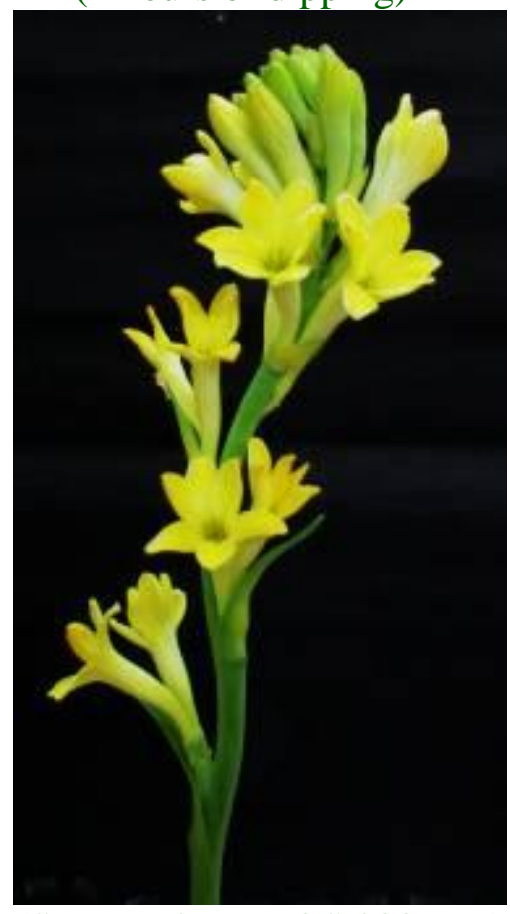

(Sucrose 2\% +HQS 200ppm)

(3 hours of dipping)

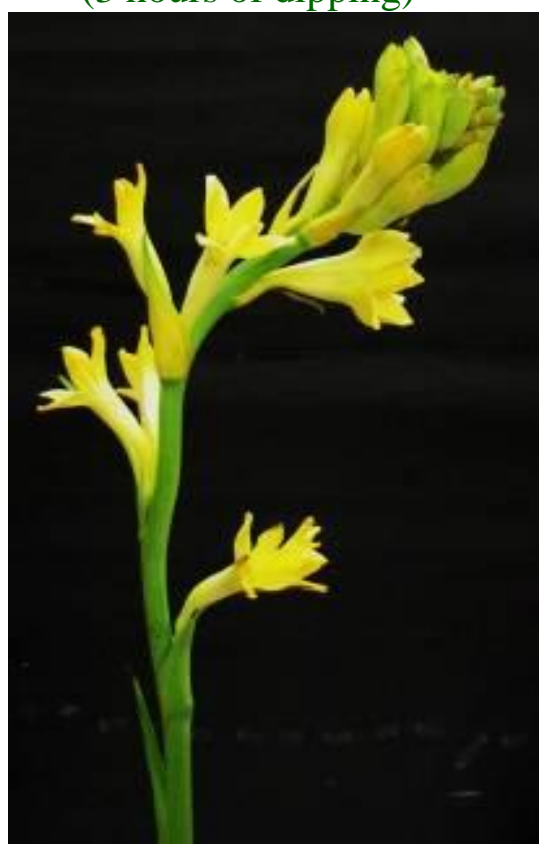

(Sucrose 2\%+HQS 200ppm)

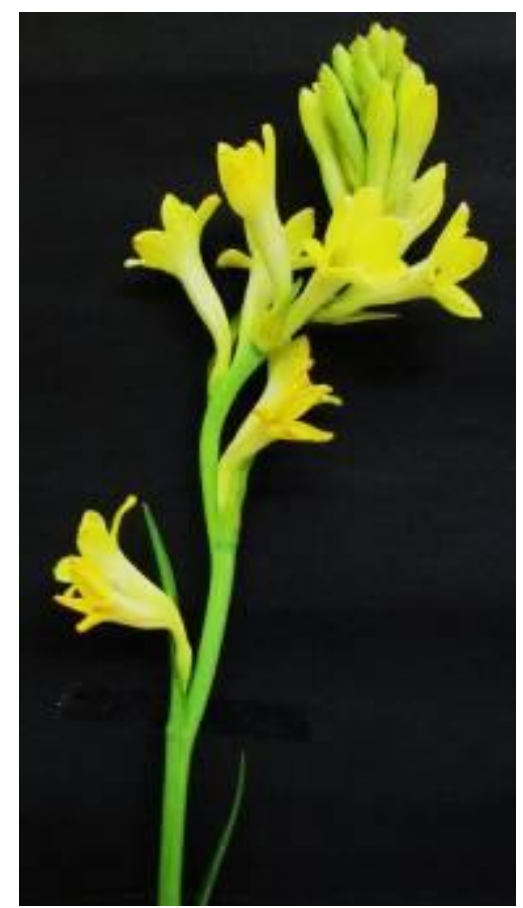

(Sucrose 2\% +Aluminium

Sulphate 200ppm)

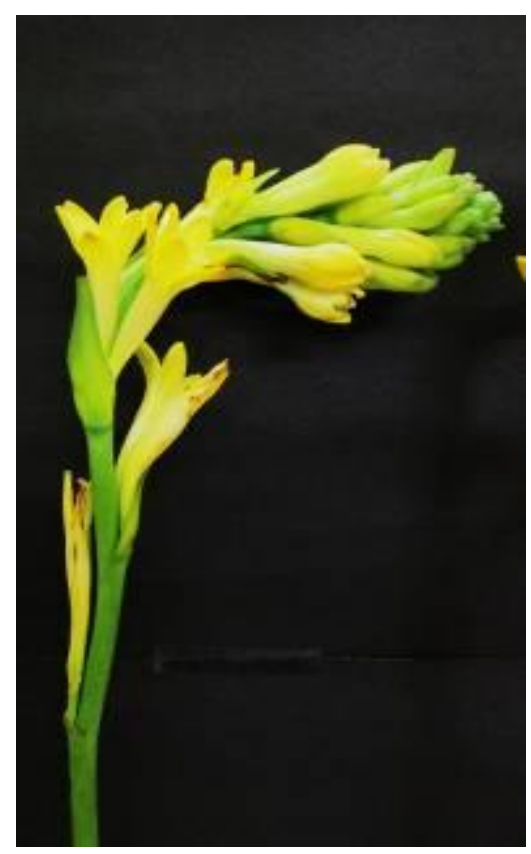

(Sucrose 2\% +Aluminium

Sulphate 200ppm) 
Fig.8 Dye uptake pattern of flowers of tuberose spikes influenced by different treatments of food dyes, floral preservatives, and dipping duration
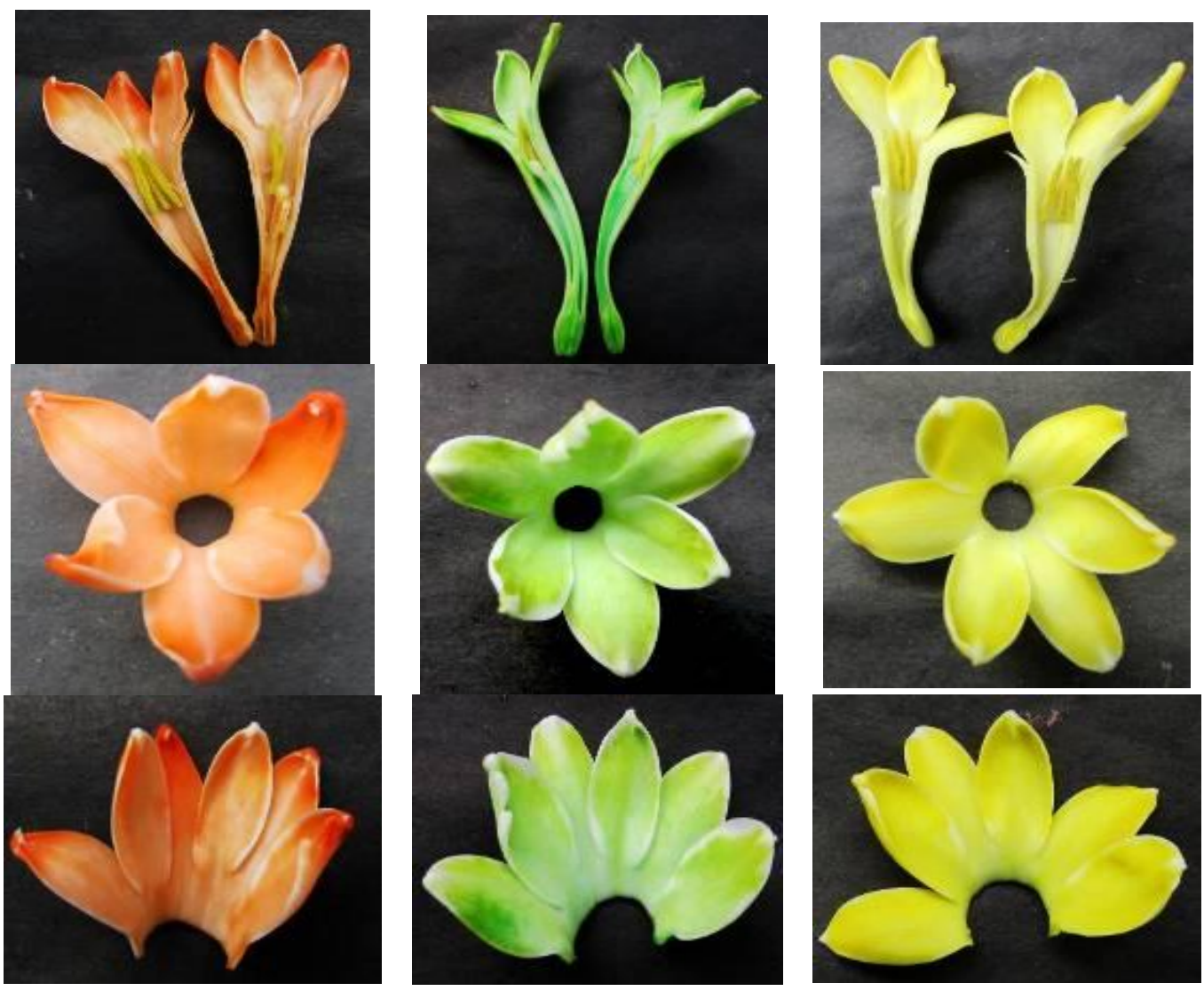

Fig.9 Quantity of dye uptake (ml/100g of spike) and vase life (days) influenced by duration of dipping on cut spikes of Tuberose (Polianthes tuberosa L.) cv. Prajwal.

$* \mathrm{H} 1-2$ hours of dipping, $\mathrm{H} 2-3$ hours of dipping

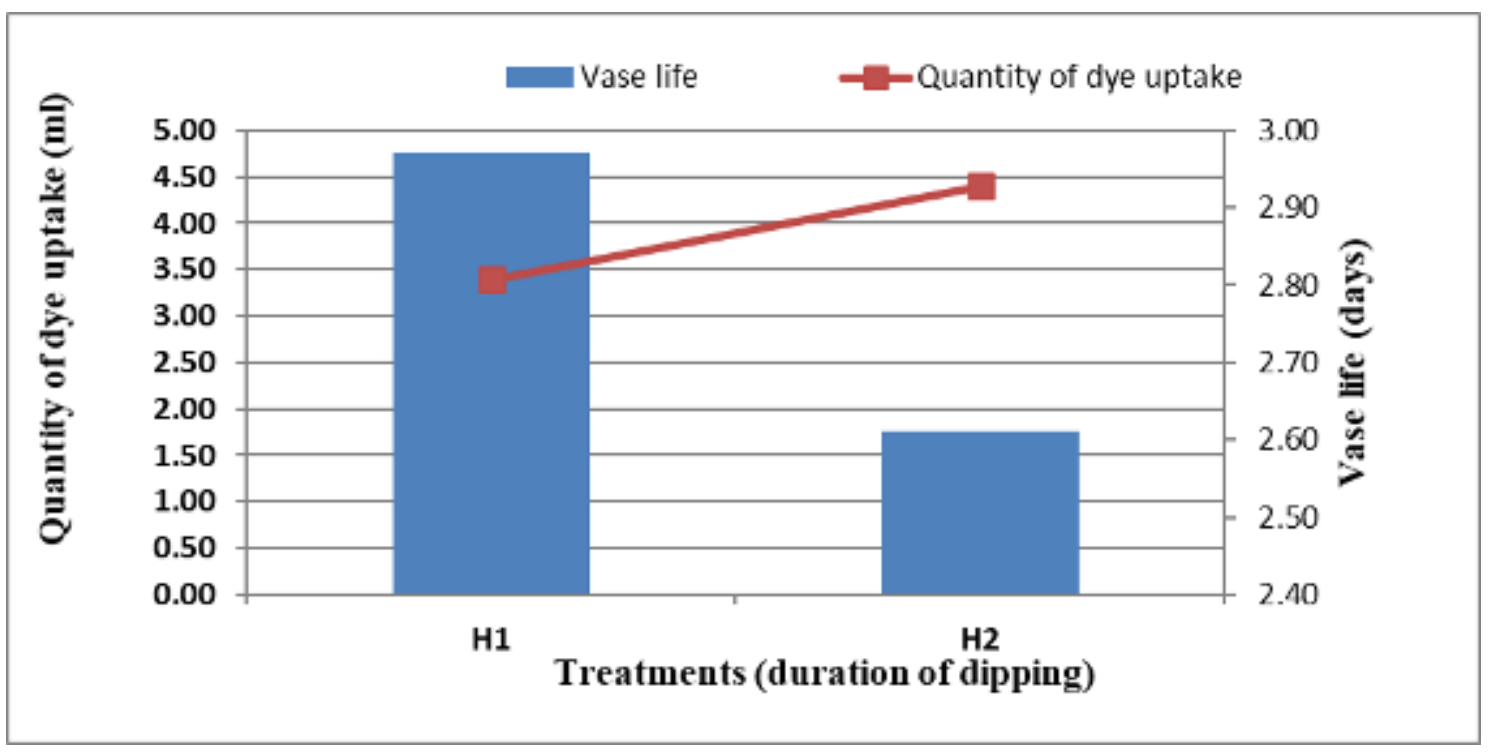


Fig.10 Quantity of water uptake (ml/100g of spike) and vase life (days) influenced by duration of dipping on cut spikes of Tuberose (Polianthes tuberosa L.) cv. Prajwal.

*H1 - 2 hours of dipping, $\mathrm{H} 2-3$ hours of dipping

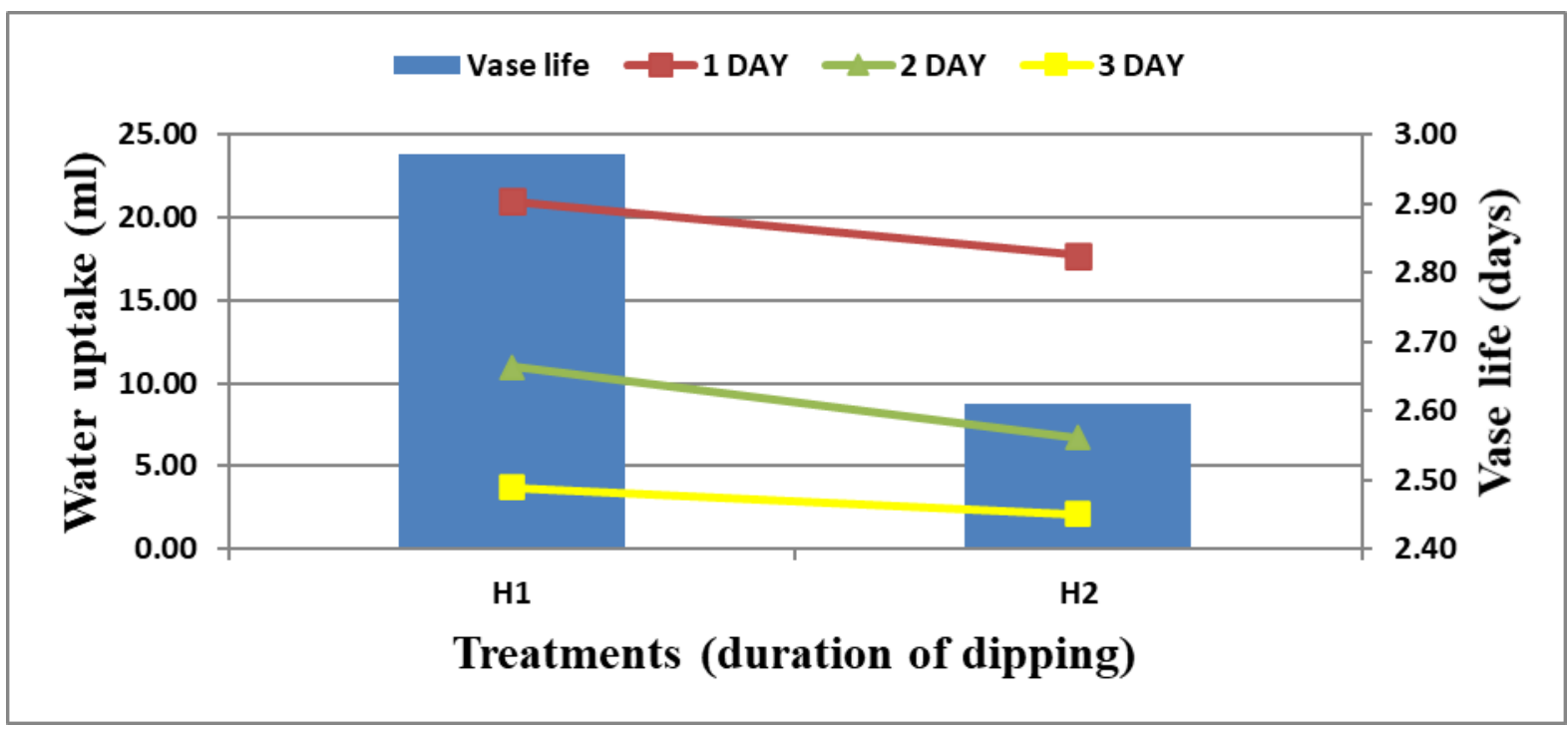

Fig.11 Quantity of dye uptake (ml/100g of spike) and vase life (days) influenced by different floral preservatives on cut spikes of Tuberose (Polianthes tuberosa L.) cv. Prajwal. *T1 - no preservatives, T2 - Sucrose $(2 \%)+$ Citric acid 300ppm, T3 - Sucrose (2\%) + Aluminium Sulphate 200ppm, T4 - Sucrose (2\%) + HQS 200ppm

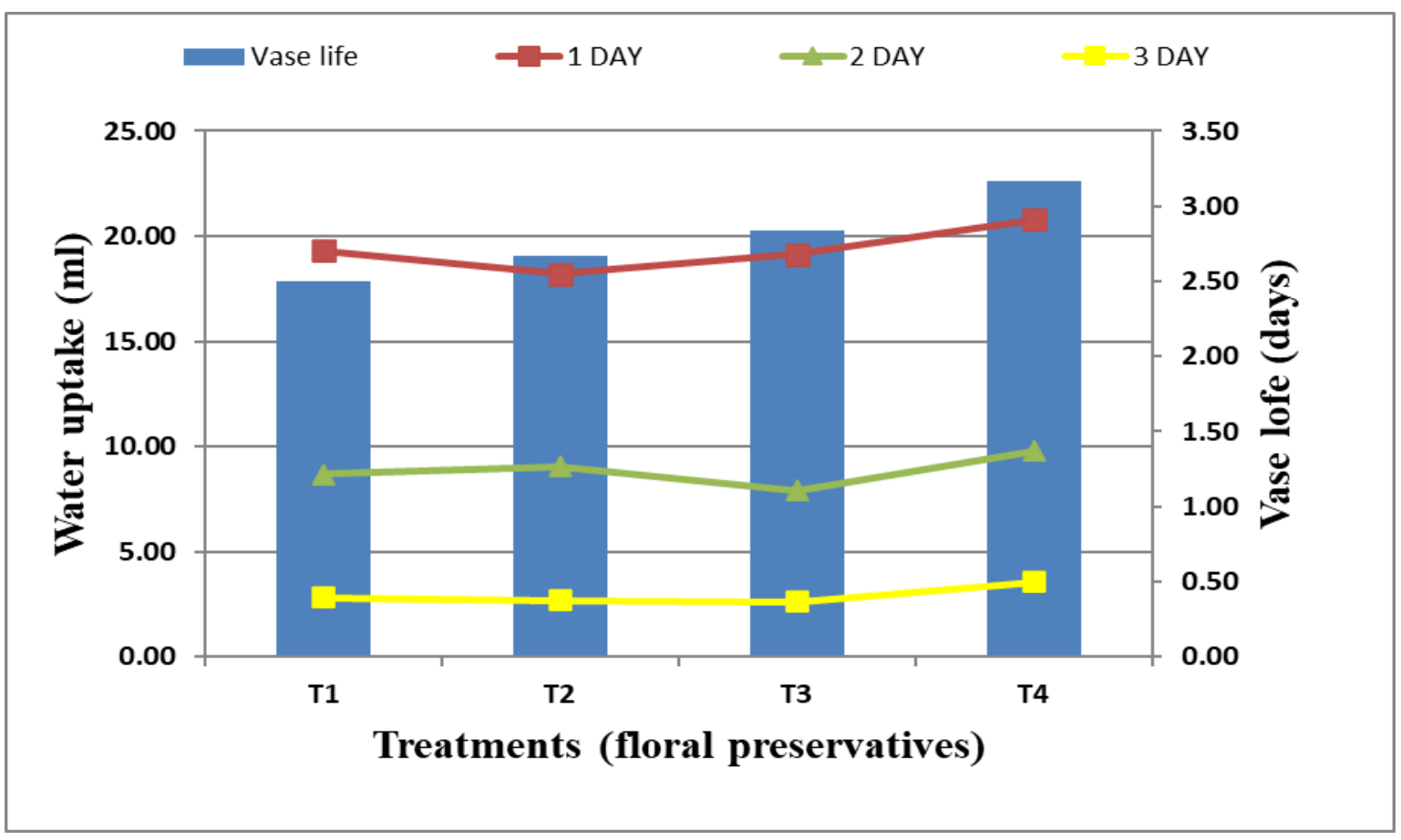


Fig.12 Acceptability score (1-9) and floret diameter ( $\mathrm{cm}$ ) influenced by different floral preservatives on cut spikes of Tuberose (Polianthes tuberosa L.) cv. Prajwal.

$\mathrm{T} 1$ - no preservatives, T2 - Sucrose $(2 \%)+$ Citric acid 300ppm, T3 - Sucrose $(2 \%)+$

Aluminium Sulphate 200ppm, T4 - Sucrose (2\%) + HQS 200ppm

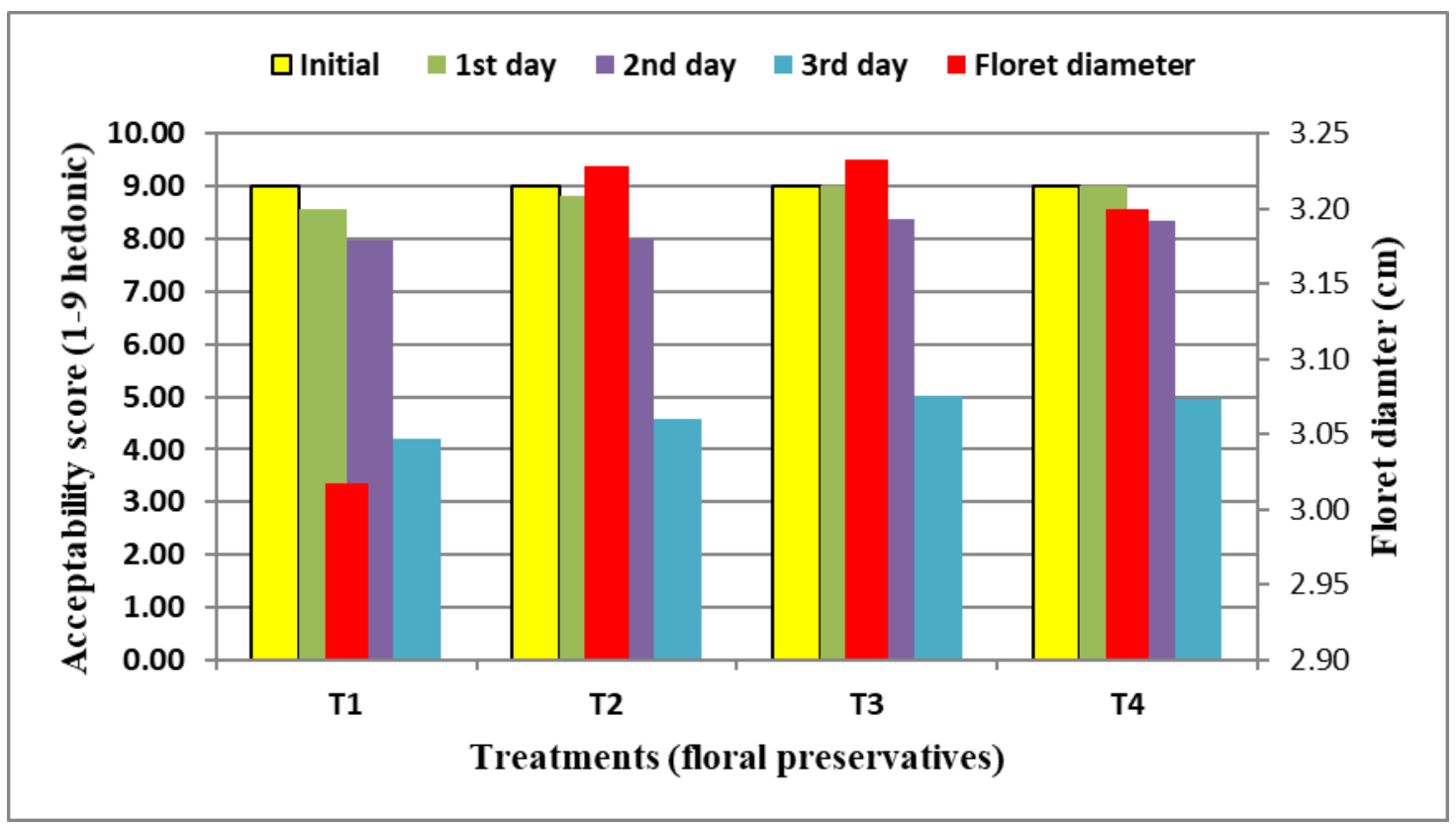

Similar findings were also concluded by Singh and Vinod, (2003) that the holding solutions containing 8-HQS (200 ppm) + sucrose $(1 \%)$ were beneficial for increasing the vase life and quality of cut China aster cv. Shashank by recording maximum solution uptake resulting in higher acceptability.

From statistically analyzed data we revealed that tuberose spikes of variety "Prajwal" could be successfully coloured by dipping in $3 \%$ solution of food dyes namely (orange-red, apple green, lemon yellow). The vase life of flowers treated with only food dyes were less than the flowers kept in plain water and dipping duration was directly responsible for reducing the vase life. However, energy sources from sucrose $(2 \%)$ in combination with germicides like HQS 200ppm not only helped to combat the ill effect of dyes but also increased the vase life along with other qualities like minimizing weight loss, increasing opening floret percentage along with floret diameter, water uptake capacity and acceptability. Also, we could find that different dyes were responsible for reduction or enhancement in vase life. Apple green was best among three followed by Lemon yellow. Quantity of dye uptake also has a significant effect on the vase life of tuberose spike. It was observed that an increase in dye uptake results in a decrease in vase life. Treatments with 3 hours of dipping (maximum dye uptake) showed minimum shelf life when compared to 2 hours of dipping. Water uptake after dying and throughout the vase life has a positive effect on the vase life of tuberose spikes. Increase in water uptake results in the increase of vase life of tuberose spikes

Therefore, it can be concluded that the preservative sucrose $2 \%+\mathrm{HQS} 200 \mathrm{ppm}$ significantly enhanced fresh weight, uptake of water, percent opened florets, vase life, and recorded a minimum physiological loss of weight of tinted tuberose spikes. After sucrose 
$2 \%+\mathrm{HQS}$ 200ppm, sucrose $2 \%+$ aluminum sulphate treatment was found better. However, sucrose $2 \%$ + aluminum sulphate showed maximum diameter of florets as compared to sucrose $2 \%+\mathrm{HQS} 200 \mathrm{ppm}$. Among food dye, apple green 3\% showed the best result as compared to the other two.

\section{References}

Anonymous. (2019). Annual Report of AICRP (All India Coordinated Research Project) on Floriculture, Published by DFR, Pune. https://dfr.icar.gov.in/Publication/Annu alReports)

Babu, D. M., Jawaharlal, M. and Kumar, M. N. (2001). Floriculture Today, Sep. issue, pp. 41-42.

Halevy, A. H. and Mayak, S. (1981). Senescence and postharvest physiology of cut flowers- Part II. Horticultural Reviews, 3: 59-143.

Hardenburg, R.E. (1990). The commercial storage of fruits, vegetables, and florist and nursery stocks. USDA Agriculture Handbook.pp.66.

Huang, K.L., Miyajima, I., Okubo, H., Shen, T.M. and Huang, T.S. (2002). Breeding of colored tuberose and cultural experiments in Taiwan. VIII International Symposium on Flower bulbs. Acta Horticulturae, 570.

Ichimura, K.; Kojima, K. and Goto, R. (1999). Effects of temperature, 8hydroxyquinoline sulphate and sucrose on the vase life of cut rose flowers. Post harvest Biology and Technology, 15 (1): 33-40.

JeomHee Park, Yoon-Jung Hwang, Sung Hwan Bae and Ki Byung Lim. (2013). Optimum condition for dyeing cut rose 'Denice' by absorption method. Current Research on Agriculture and Life Sciences, 31(1): 58-62.

Kumari, S, Deepika., Raghupathi, B., Sarika,
K and Deb, P. (2018). Value Addition of Tuberose (Polianthes tuberosa L.) cv. Calcutta Double Cut Flower by Colouring with Edible Dyes. Chemical Science Review and Letters, 7(25): 158164.

Kumari, S. and Deb, P. (2018). Effect of Tinting on Value Addition of Tuberose (Polianthes tuberosa L.) cv. Prajwal. International Journal of Bio-resource and Stress Management, 9: 314-322.

Kumari, S., Raghupathi, B., Sarika, K. and Deb, P. (2018). Effect of Different Preservatives on Vase-Life of Cut Tuberose (Polianthes tuberosa L.) cv. Calcultta Single. International Journal of Current Microbiology and Applied Sciences, 7(01): 1651-1657.

Mahalanobis, P.C. (1932). Statistical notes for Agricultural workers. NO. 4. Rice and potato Experiment at Sriniketan. Indian Journal of Agricultural Science, 2:694703.

Mekala, P., Ganga, M. and Jawaharlal, M. (2012). Artificial colouring of tuberose flowers for value addition. South Indian Horticulture, 60: 216-223.

Marousky, F. J. (1969). Vascular blockage, water absorption, stomatal opening and respiration of cut 'Better Times' roses treated with 8-hydroxyquinone citrate and sucrose. Journal of the American Society of Horticultural Science, 94: 223-226.

Murthy, S.K. and Negi, S. (1981). Extension of vase life of chrysanthemum cut flower by preservatives. Indian Journal of Horticulture, 30: 246-248.

Ranchana, P., M. Ganga, M. Jawaharlal and Kannan, M. (2017). Standardization of Tinting Techniques in China aster cv. Local White. International Journal of Current Microbiology and Applied Sciences, 6(9): 27-31.

Ranganna, S. 1997. Handbook of Analysis and Quality Control for Fruits and 
Vegetable Products.2nd ed., Tata Mac Graw Hill Publication Co., New Delhi.pp.112.

Reddy, B. S. and Singh, K. (1996). Effect of aluminum sulphate and sucrose on vase life of tuberose. Journal of Maharashtra Agriculture University.; 21(2):201-203.

Reddy, B. S., Singh, K. and Ganacharappa, PM. (1997). Influences of 8- hydroxyl quinolone sulphate and sucrose on post harvest physiology of tuberose of tuberose cv. Double. Karnataka The Journal of Agricultural Science; 10(4): 1049-1054.

Safeena, S. A., Thangam, M. and Singh, N. P. (2016). Value addition of tuberose (Polianthes tuberosa L.) Spikes by tinting with different edible dyes, Asian Journal of Research in Biological and Pharmaceutical Sciences, 4(3): 89 - 98.

Singh, K. P. and Vinod, K. S. (2003). Vase life and quality of China Aster (Callistephus chinensis) cut flowers as influenced by holding solutions. Journal of Ornamental Horticulture, 6(4): 362-366.

Song, C. Y. Shin, D. G. Woo, I. S. and Lee, J. S. (1992). Studies on the vase life extension of cut flower gladiolus. Korean Journal of Horticultural Science and Technology, 33(1):95-101.

Sowmeya, S., Kumaresan, S. and Sanmuga priya, L. (2017). Effect of Multi Colours in Tinting Techniques in Cut Flowers (Rose and Carnation). Chemical Science Review and Letters, 6(24), 2250-2253.

Van Meteren, U., Van Gelder, A., Van Ieperen, W. and Slootweg, C. (2001). Should we reconsider the use of deionized water as control vase solutions. Acta Horticulturae, 543: 257264.

Varu, D. K. and Barad, A. V. (2007). Effect of floral preservatives on quality and vase life of cut flowers tuberose (Polianthes tuberosa L.) cv. Double. Asian J. Horti.; 3(1): 169-172.

Viradia R. R., Bajad A. and Polara N.D. (2015). Value Addition through Use of Dye Chemicals and Floral Preservatives in Tuberose (Polianthes tuberosa L.) $\mathrm{Cv}$. Double. International Journal of Forestry and Horticulture. 1(1): 1-4. (www.arcjournals.org).

\section{How to cite this article:}

Bijay Kumar Baidya and Suhrita Chakrabarty. 2020. Increasing Vase Life of Tinted Spikes of Polianthes tuberosa Linn. cv. Prajwal by Adding Floral Preservatives. Int.J.Curr.Microbiol.App.Sci. 9(08): 2736-2758. doi: https://doi.org/10.20546/ijcmas.2020.908.310 